\title{
OFFICE OF ANTICORRUPTION AND INTEGRITY 2018 ANNUAL REPORT
}




\section{OFFICE OF \\ ANTICORRUPTION \\ AND INTEGRITY \\ 2018 ANNUAL REPORT}


(C) 2019 Asian Development Bank

6 ADB Avenue, Mandaluyong City, 1550 Metro Manila, Philippines

Tel +632632 4444; Fax +6326362444

www.adb.org

Some rights reserved. Published in 2019.

ISBN 978-92-9261-566-6 (print), 978-92-9261-567-3 (electronic)

ISSN 2226-7247 (print), 2226-7255 (electronic)

Publication Stock Number: ARM190077-2

DOI: http://dx.doi.org/10.22617/ARM190077-2

The views expressed in this publication are those of the authors and do not necessarily reflect the views and policies of the Asian Development Bank (ADB) or its Board of Governors or the governments they represent.

ADB does not guarantee the accuracy of the data included in this publication and accepts no responsibility for any consequence of their use. The mention of specific companies or products of manufacturers does not imply that they are endorsed or recommended by ADB in preference to others of a similar nature that are not mentioned.

By making any designation of or reference to a particular territory or geographic area, or by using the term "country" in this document, $\mathrm{ADB}$ does not intend to make any judgments as to the legal or other status of any territory or area.

This work is available under the Creative Commons Attribution 3.0 IGO license (CC BY 3.0 IGO) https://creativecommons.org/licenses/by/3.o/igo/. By using the content of this publication, you agree to be bound by the terms of this license. For attribution, translations, adaptations, and permissions, please read the provisions and terms of use at https://www.adb.org/terms-use \#openaccess.

This CC license does not apply to non-ADB copyright materials in this publication. If the material is attributed to another source, please contact the copyright owner or publisher of that source for permission to reproduce it. ADB cannot be held liable for any claims that arise as a result of your use of the material.

Please contact pubsmarketing@adb.org if you have questions or comments with respect to content, or if you wish to obtain copyright permission for your intended use that does not fall within these terms, or for permission to use the ADB logo.

Corrigenda to ADB publications may be found at http://www.adb.org/publications/corrigenda.

Notes:

All photos by $A D B$ except when otherwise stated.

In this publication, “\$” refers to United States dollars. 


\section{CONTENTS}

ABBREVIATIONS

vi

2018 AT A GLANCE

viii

EXECUTIVE SUMMARY

STRENGTHENING INTEGRITY IN ADB OPERATIONS 8

Complaints

Investigations

Remedial Actions Imposed by Integrity Oversight Committee

FOSTERING A RESPECTFUL WORKPLACE

The Respectful Workplace Unit's Visitors

Advisories and Investigations

ASSESSING AND MANAGING

PROJECT INTEGRITY RISKS

Project Procurement-Related Reviews

Integrity Risk Management Reviews

MITIGATING RISKS THROUGHINTEGRITY

DUE DILIGENCE

Integrity Due Diligence

Preemployment Screening

Know-Your-Customer Requests

SHARING KNOWLEDGE AND COLLABORATING

WITH STAKEHOLDERS

Knowledge-Sharing Events

Collaboration

Knowledge Products

Regional Technical Assistance Projects 


\section{INTEGRITY RESPECT}

TRUST CREDIBILITY ACCOUNTABILITY TRANSPARENCY RESPONSIVENESS COMMITMENT INNOVATION TEAMWORK

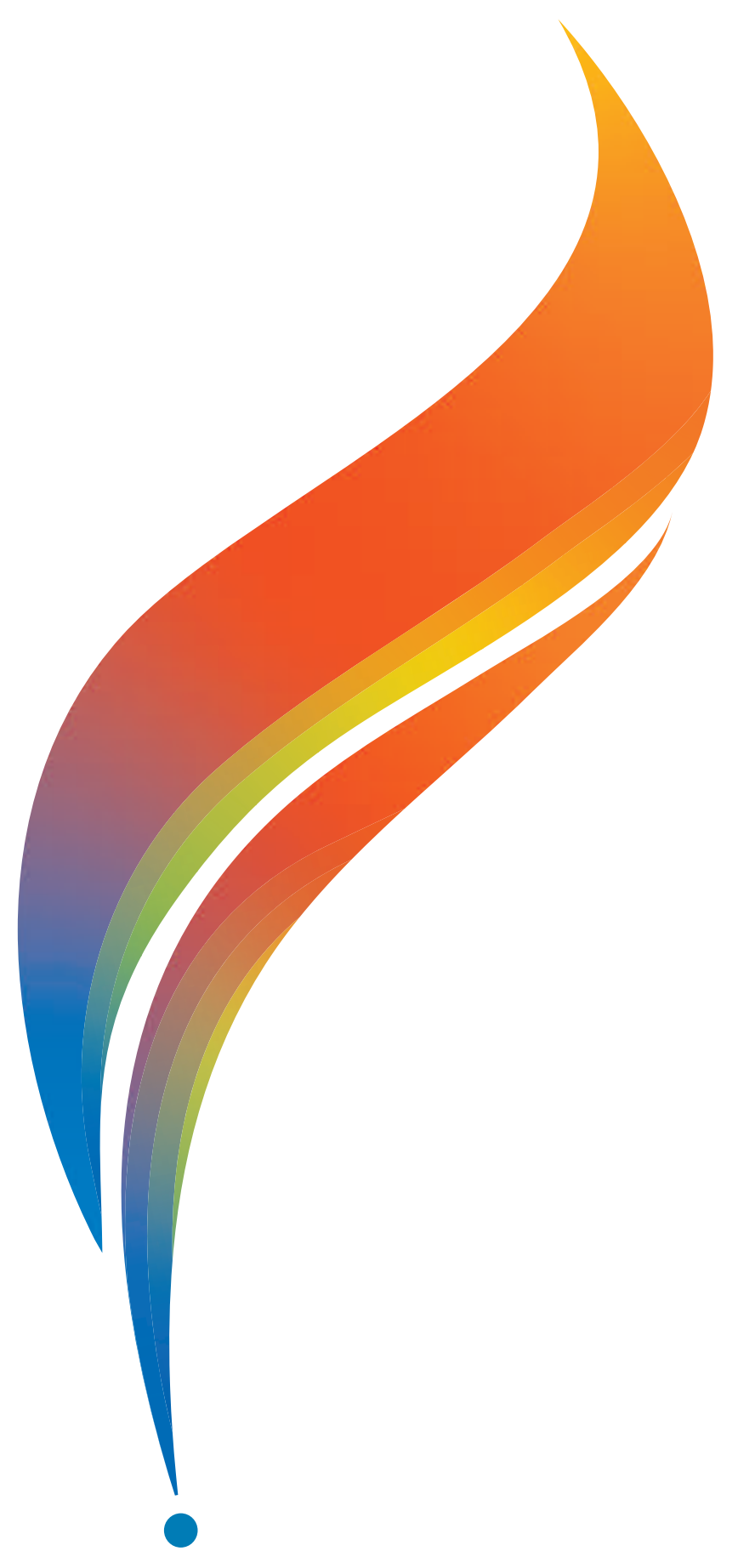




\section{ABBREVIATIONS}

ADB

AIID

AIOD-DU

AIOD-RU

AIOD-RWU
Asian Development Bank

Investigations Division,

Office of Anticorruption and Integrity
Due Diligence Unit,

Office of Anticorruption and Integrity

Review and Outreach Unit, Office of Anticorruption and Integrity

Respectful Workplace Unit, Office of Anticorruption and Integrity

anti-money laundering and combating the financing of terrorism

BEPS

base erosion and profit shifting

BPMSD

Budget, Personnel, and

Management Systems Department

DMC

developing member country 
PPFD

Procurement, Portfolio, and

Financial Management Department

PPRR

project procurement-related review

\section{TA}

technical assistance 


\section{AT A GLANCE}

\section{Investigations Division}

Complaints Opened

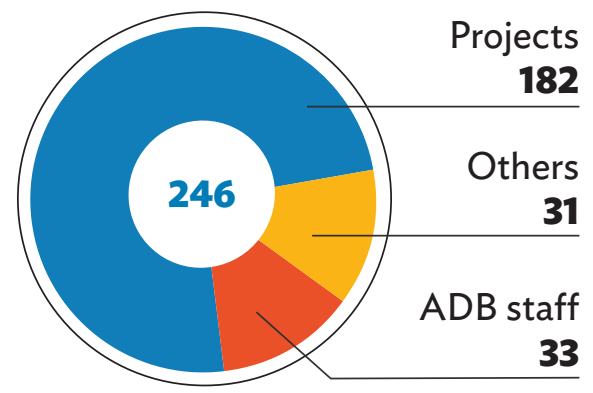

$64 \%$ of complaints

were from external parties

\section{Sources of Complaints}

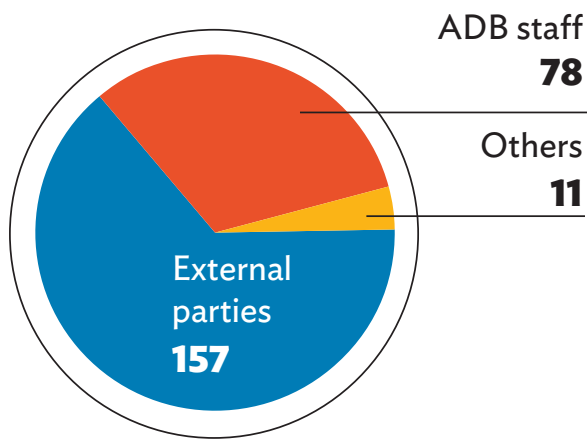

\section{Investigations Opened}

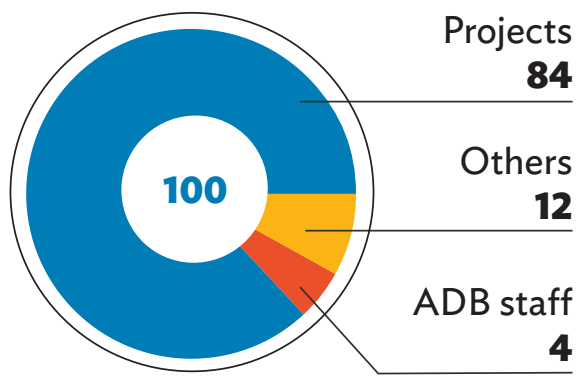

100 complaints met the assessment criteria and were converted into investigations

\section{Remedial Actions for External Parties}

\begin{tabular}{|l|r|r|}
\hline Action Taken & Firms & Individuals \\
\hline Sanctioned & 80 & 25 \\
Reprimanded & 16 & 14 \\
\hline Cautioned & 13 & 3 \\
\hline Cross-debarred & 272 & 48 \\
\hline
\end{tabular}

OAI also submitted three investigation reports of staff misconduct to the Budget, Personnel, and Management Systems Department, which imposed disciplinary actions in two cases. 


\section{Complaints Closed}

Did not meet assessment criteria With remedial action

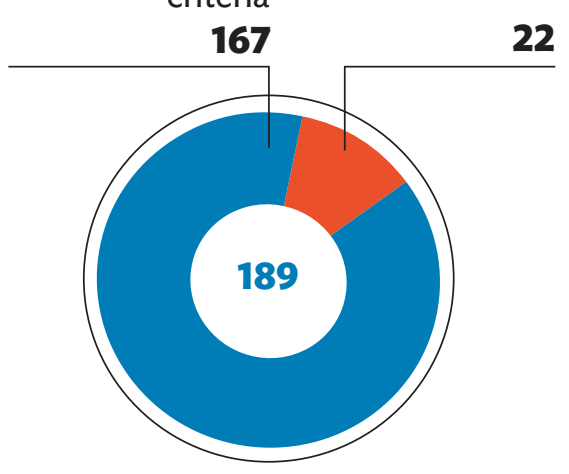

\section{Investigations Closed}

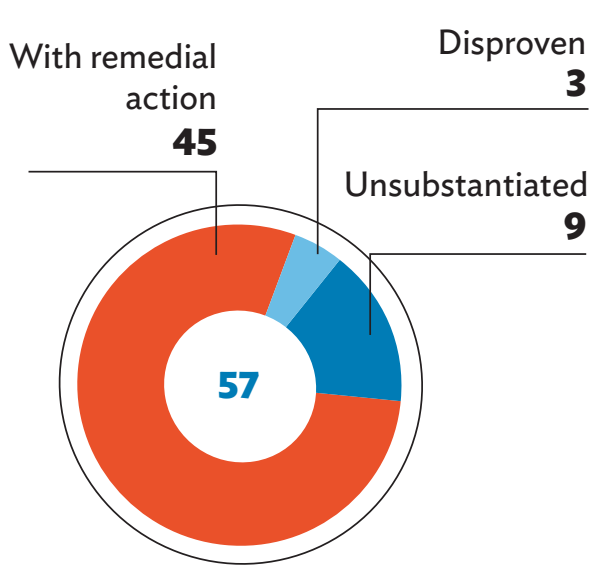

\section{Respectful Workplace Unit}

Matters Reviewed

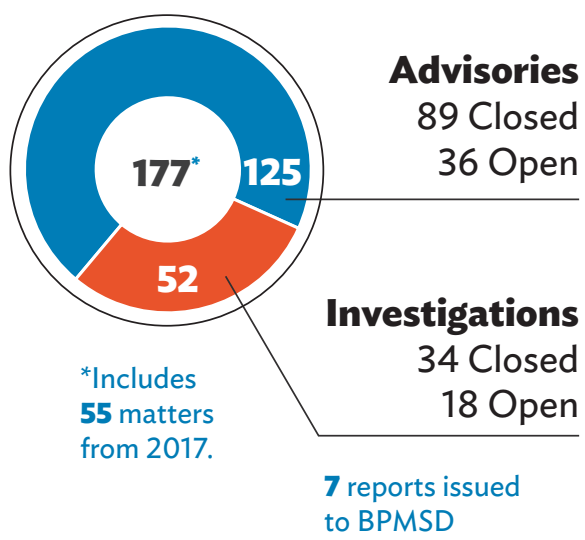

BPMSD = Budget, Personnel, and Management Systems Department.
Types of Matters
Bullying and harassment

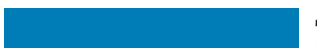

72 33
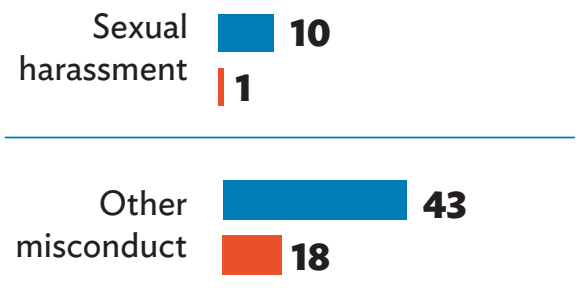

Advisories Investigations 


\section{Review and Outreach Unit}

\section{Proactive Reviews}

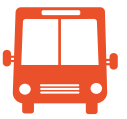

3

Transport

Papua New Guinea

Timor-Leste

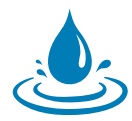

2

Water

Sri Lanka

Viet Nam

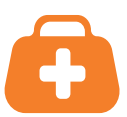

1

Health

Mongolia

Value of projects covered

$\$ 1.7$ billion

Value of contracts reviewed

$\$ 462$ million

Learning Events Conducted

Learning Events Participants

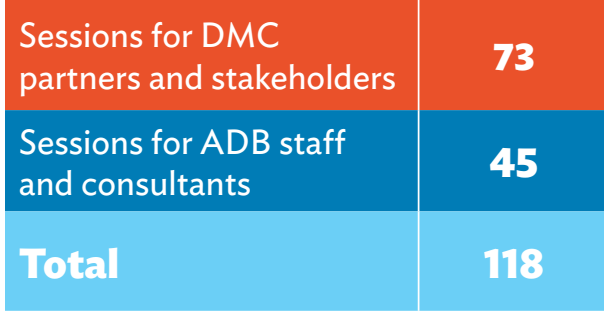

Over $\mathbf{6 8 \%}$ of sessions for

ADB staff and consultants

were on Respect in the Workplace.

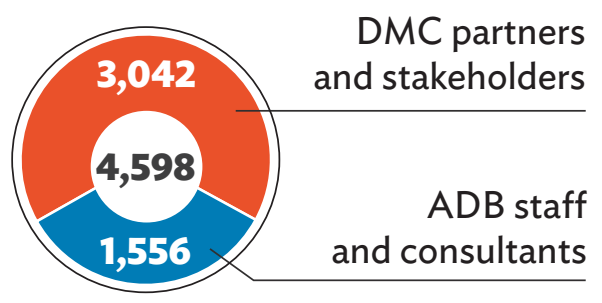

Of OAl's outreach beneficiaries, $66 \%$ were DMC representatives and development partners.

$\mathrm{DMC}=$ developing member country

\section{Due Diligence Unit}

Entities reviewed for

integrity due diligence 


\section{“ADB must continue to fight all types of corruption, individually and collectively, as One ADB."}

Strategy 2030 sets the course for efforts of the Asian Development Bank (ADB) to respond effectively to the region's changing needs. One of the seven priorities under Strategy 2030-strengthening governance and institutional capacity-includes implementing anticorruption measures in all ADB projects and programs. The Office of Anticorruption and Integrity $(\mathrm{OAI})$ plays a key role in supporting the implementation of Strategy 2030.

OAI promotes good governance and builds the capacity of developing member countries (DMCs) with its focus on fighting corruption; its tax integrity and anti-money laundering initiatives, as well as measures it has adopted to combat the financing of terrorism; the Anti-Corruption Initiative for Asia and the Pacific, formerly known as the ADB-Organisation for Economic Co-operation and Development Anticorruption Initiative for Asia and the Pacific; and its efforts to improve integrity and respect in the workplace.

In 2018, OAl's Investigations Division (AIID) reinforced its complaint assessment function and made wider use of remedial actions other than debarment. AIID opened 246 complaints, of which 32 (13\%) 
pertained to integrity violations by ADB staff. The division assessed and concluded 189 complaints, and went on to investigate 100 others. At the end of 2018, 202 complaints were under assessment.

AIID concluded 57 investigations in 2018, and 45 of these resulted in 151 remedial actions on 109 firms and 42 individuals. Eighty firms and 25 individuals were sanctioned by ADB - both record numbers. These remedial actions comprised debarments proposed by OAI and accepted by 58 firms and 5 individuals, debarments imposed by the Integrity Oversight Committee on 14 firms and 19 individuals, temporary suspension of 1 firm, and conditional non-debarment of 7 firms and 1 individual. OAI also issued reprimands to 16 firms and 14 individuals, and cautioned 13 firms and 3 individuals. In addition, ADB cross-debarred 272 firms and 48 individuals.

This use of a variety of remedial actions enhanced integrity within ADB-related activities and the general business environment in DMCs. OAI submitted three investigation reports of staff misconduct to the Budget, Personnel, and Management Systems Department (BPMSD), which imposed disciplinary action in two cases. The third case was under assessment at the end of 2018. See Appendix A for information on these investigations.

The Respectful Workplace Unit (AIOD-RWU) continued to promote respect and raised awareness on harassment in the workplace. In 2018, it received 131 visitors, leading to the opening of 122 workplace matters relating to harassment, bullying, and other misconduct. This total was $82 \%$ higher than the 2017 figure.

Including cases from the previous year, 177 workplace matters were reviewed by AIOD-RWU in 2018. The unit provided advice in 125 of these cases and investigated 52. At the end of 2018, 89 (71\%) of these advisories and 34 (65\%) of matters investigated were closed. Seven investigation reports were completed and submitted to BPMSD, which issued written censure in one case and written reprimands in two cases, and is considering appropriate remedial action for the rest. Eighteen investigations were open at year-end. 
The Review and Outreach Unit (AIOD-RU) conducted one project procurement-related review (PPRR) and five follow-up reviews in 2018. Three PPRR reports on projects with contracts valued at $\$ 462$ million, and withdrawal applications totaling $\$ 171$ million, were issued.

These reports recommended ways of strengthening procurement, financial management, asset inspection, and the capacity of the executing and implementing agencies. AIOD-RU also conducted integrity risk management reviews of 63 pre-approval project documents.

The Due Diligence Unit (AIOD-DU) screened ADB counterparties for integrity-related, money laundering, terrorist financing, tax integrity-related, and reputational risks. AIOD-DU assisted the ADB departments and offices concerned in conducting integrity due diligence (IDD) advisories and reviews for 871 entities - $12 \%$ more than in 2017. The number of IDD advisories and reviews done for the Private Sector Operations Department was still the highest, at 422 (48\% of the entities reviewed). AIOD-DU preemployment screenings, carried out in collaboration with BPMSD, increased by $37 \%$, to 651 , from the 2017 total.

A pilot program launched by OAI introduced an IDD process for ADB-administered consulting services, to ensure the existence of adequate and systematic controls that would enable ADB to identify and address potential integrity and reputational risks in consultant recruitment.

OAI continued to work with the financial intelligence units in Bhutan, Mongolia, Papua New Guinea, and the Philippines to institute anti-money laundering and/or to combat the financing of terrorism through regulatory measures and to build the capacity of financial services authorities, domestic banks, and nonbank financial institutions.

OAI also provided in-country technical assistance to the Federated States of Micronesia, Maldives, the Marshall Islands, Papua New Guinea, the Philippines, 
Samoa, and Thailand, to help them establish and strengthen legal and institutional systems that would increase tax transparency and avert tax evasion. Action plans for exchange of information on request were developed in close cooperation with the Federated States of Micronesia, the Marshall Islands, Papua New Guinea, Samoa, and Thailand.

Knowledge sharing remained an overarching priority for OAI. Its 118 learning events drew 4,598 participants from ADB, DMCs, and other stakeholders. The DMC representatives and development partners who attended 72 of these learning sessions made up about $65 \%(3,042)$ of the beneficiaries of OAl's outreach. The other 45 face-to-face training sessions were held for over $1,500 \mathrm{ADB}$ staff and consultants from headquarters and resident missions. Over 68\% (31) of these sessions were on Respect in the Workplace.

To promote respectful workplace behavior and remind ADB staff to uphold the highest ethical standards, OAI launched an e-learning course with two modules-Anticorruption and Integrity, and Respect at Work-which achieved a 98\% completion rate.

The "iACT to fight corruption!" campaign continued to be ADB's centerpiece anticorruption and integrity initiative.

This awareness-raising effort culminated in the celebration of International Anti-Corruption Day in December 2018, with ADB calling for a sustained push against corruption and for better governance, particularly in education and environmental management. iPLAY iACT, a bespoke arcade game featured at the iACT exhibit, was played more than 3,700 times, testing 1,152 players' knowledge of integrity violations.

OAl published the Asset Inspection for Project Integrity reference guide to provide executing and implementing agencies with a practical framework for asset inspection in ADB-financed projects. In addition, OAI produced two learning videos - $A D B$ Anticorruption Policy Explainer: Protecting Development Projects from Corruption and Fostering Collaboration and Commitment: ADB's PPRR of Jaipur Metro Rail Corporation - which highlighted measures 
taken to protect development projects from integrity violations.

OAl expanded its online reach by maintaining the $\mathrm{OAI}$ website, Facebook page, Twitter account, and dedicated intranet webpage for $A D B$ staff. OAI also distributed four issues of the quarterly Integrity e-Bulletin and 12 issues of the monthly Respect at Work e-bulletin. These e-bulletins provide guidance in detecting and preventing integrity violations and in promoting a respectful and professional workplace.

OAI also continued to support ADB operations and enhance information exchange with its stakeholders. OAI provided 717 integrity advisories on cofinancing and other partnerships; conflict of interest; contract variations for sanctioned entities; and general advisories on cross-debarment, eligibility of sanctioned entities, and anticorruption clauses in project documents, agreements, and contracts, among other topics.

Through collaboration with peer institutions, OAI benefited from the exchange of integrity and respect-at-work practices and challenges. ADB was accepted as a member of the Ethics Network of Multilateral Organizations in 2018. OAl participated in the Heads of Integrity Meeting hosted by the World Bank in the United States in June 2018, and collaborated with the Green Climate Fund in hosting the 19th Conference of International Investigators in the Republic of Korea in October, conducting training sessions in practical approaches to project integrity reviews and investigations into workplace harassment, and hosting the Heads of Integrity Meeting as a side event at the conference.

Also in 2018, OAl led an evaluation of the Anti-Corruption Initiative for Asia and the Pacific to assess its relevance and effectiveness in supporting its 31 members. According to the evaluation report, the initiativethe largest anticorruption network in the world-met members' expectations and complemented other anticorruption initiatives and networks in the region. 


\section{Preparing for Tomorrow}

In 2019, OAI will continue to fulfill its mandate by further reassessing, realigning, and rebalancing its resources, using technology and partnerships to deliver value to its stakeholders. It will prioritize improvements in its work efficiency by using current information technology systems to best advantage and by developing a streamlined case management system with intelligent data analytics providing better support for its operations.

To manage the Investigation Division's caseload more effectively, OAI will focus on making corrective changes in its procedures, incorporating higher-quality screening methods and constructive remedial measures in partnership with other ADB stakeholders.

The Review and Outreach Unit will develop country and/or sector integrity risk profiles and capitalize on its knowledge-sharing practices to build ADB and DMC capacity to safeguard development funds from misuse.

The Respectful Workplace Unit's outreach programs will continue to raise awareness on harassment in the workplace, including encouraging staff to report any incident of sexual harassment for investigation. Its activities will be assessed as part of a 2-year pilot review, and recommendations will be made regarding its future direction.

OAI will also partner with DMCs and leverage its resources to assist them in further enhancing their tax integrity framework through capacity-building initiatives.
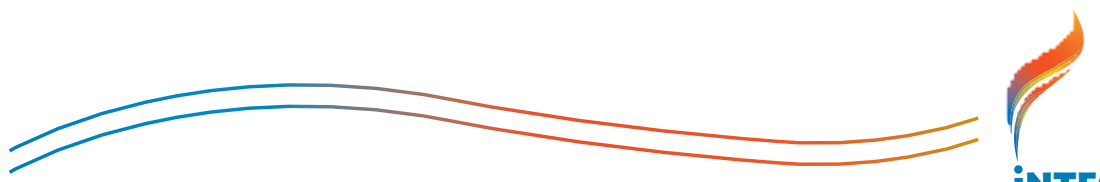

iNTEGRITY 


\section{STRENGTHENING INTEGRITY IN ADB OPERATIONS}

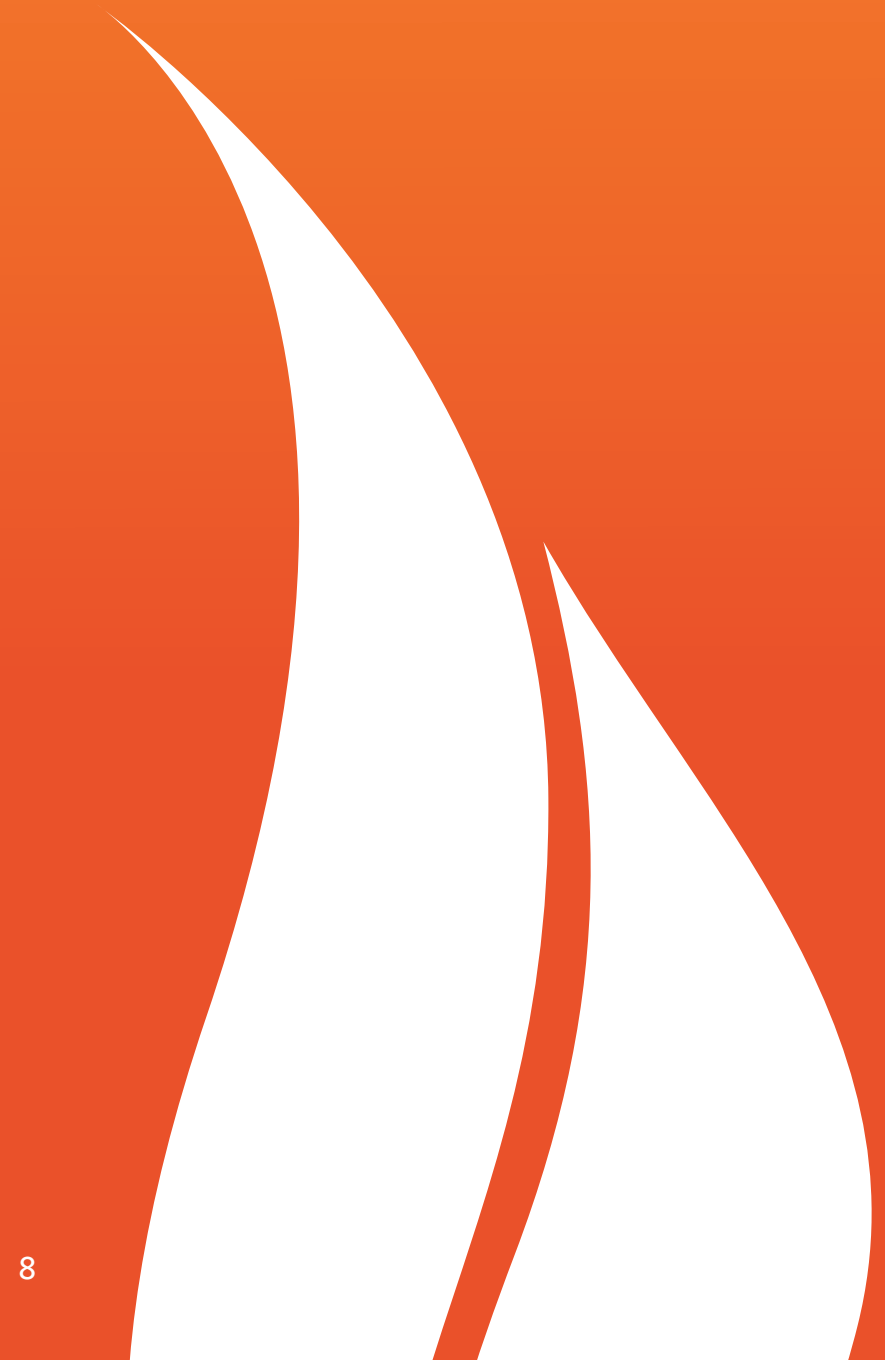




\section{Complaints}

At the start of 2018, the Asian Development Bank (ADB) Office of Anticorruption and Integrity (OAI) had 379 open cases, consisting of 245 complaints and 134 investigations.

Figure 1:Types of Complaints

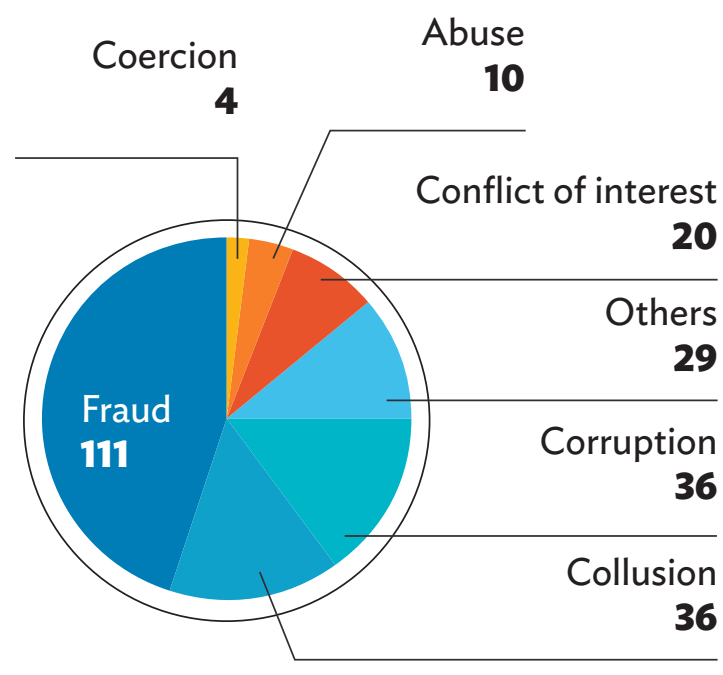

OAl's Investigations Division (AIID) registered 246 new complaints of alleged integrity violations in ADB-related activities and staff integrity misconduct-9\% higher than the number of complaints in 2017. Forty-five percent (111) of these complaints pertained to allegations of fraud (Figure 1).

Thirty-nine open complaints remaining from 2015 and 2016, and 90\% of 226 complaints registered in 2017, were closed or converted in 2018. OAl concluded the assessment of 189 complaints, 37\% higher than the number in 2017 (Figure 2).

Eighty-nine percent of the complaints were closed as they did not meet the assessment criteria and $11 \%$ were closed with remedial actions (Figure 3).

As of 31 December 2018, 202 complaints remained open. OAI converted 100 complaints into investigations as they met the screening criteria. ${ }^{2}$

\footnotetext{
OAI may close complaints where sufficient action has been taken by other ADB departments or executing agencies and/or national authorities.

2 Complaints are converted into investigations if the allegations are within mandate, credible, verifiable, and material, or for other relevant considerations.
} 
Figure 2: Received and Closed Complaints (2013-2018)
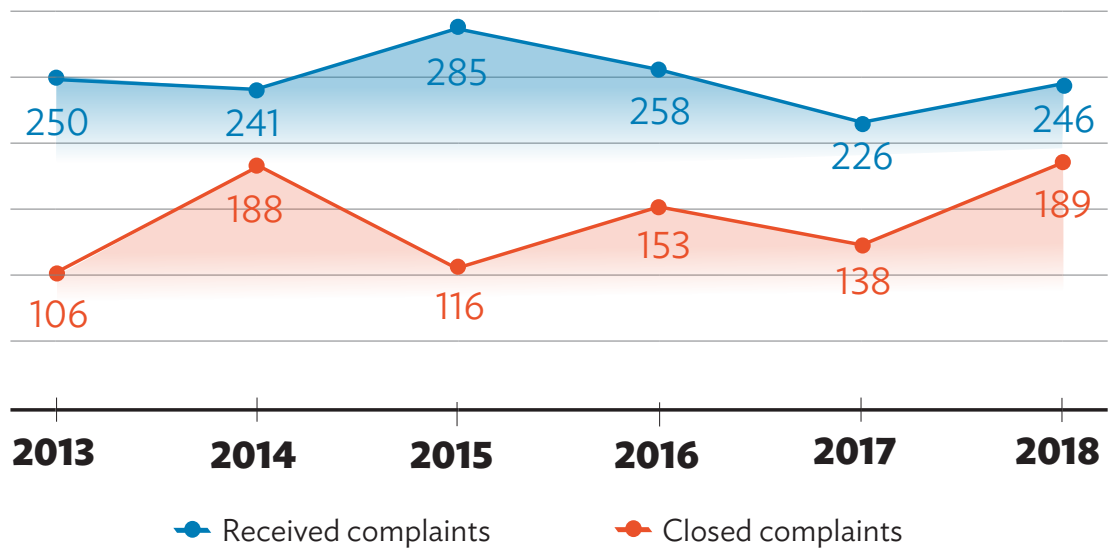

Source: Asian Development Bank (Office of Anticorruption and Integrity).

Figure 3: Complaints Closed

Did not meet assessment criteria

\begin{tabular}{|c|c|}
\hline Not credible & \\
\hline Not verifiable & $23 \%$ \\
\hline Not within mandate & $8 \%$ \\
\hline Not material & \\
\hline
\end{tabular}

With remedial action

\begin{tabular}{l|l} 
Reprimand issued & $\begin{array}{c}4 \% \\
\text { Others }\end{array}$ \\
\hline Caution issued & $1 \%$
\end{tabular}

a Actions taken by other ADB departments or external agency, or incorporated into related complaints.

Source: Asian Development Bank (Office of Anticorruption and Integrity). 


\section{Investigations}

Of the 100 investigations in 2018, $72 \%$ pertained to allegations of fraudulent practice (Figure 4).

OAl concluded 57 investigations -45 (79\%) resulted in remedial actions and 12 were unsubstantiated and disproven (Figures 5 and 6). At the end of 2018, 177 investigations remained active.
Figure 4: Types of Investigations

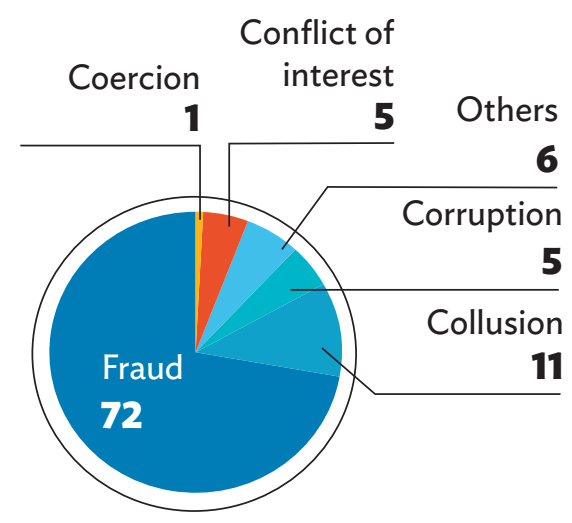

Figure 5: Opened and Closed Investigations, 2013-2018

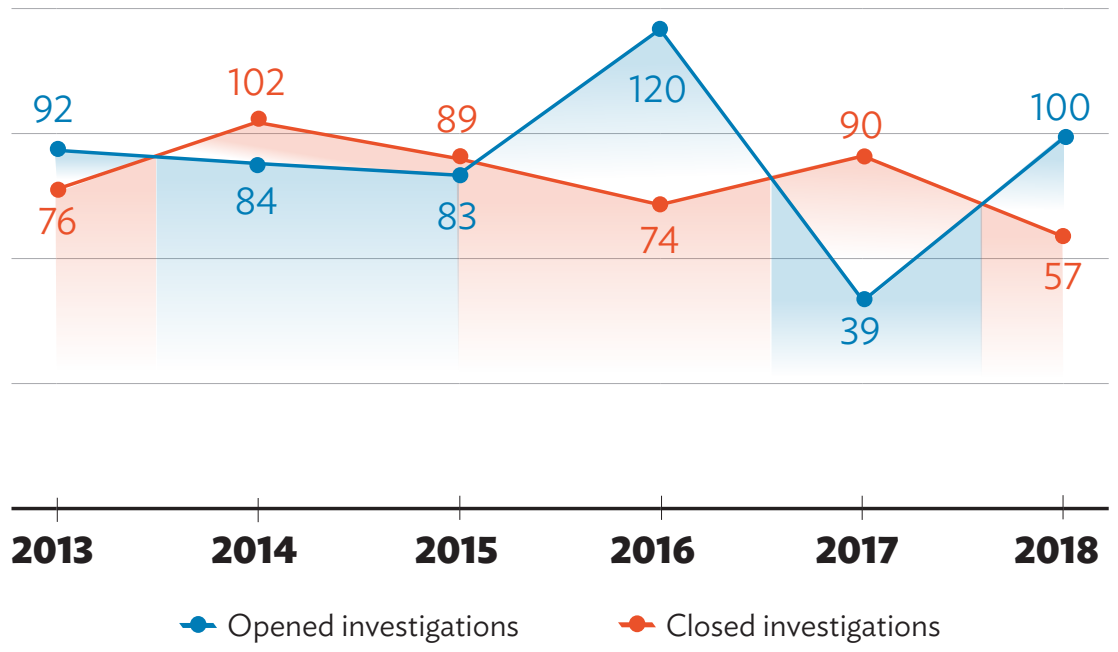

Source: Asian Development Bank (Office of Anticorruption and Integrity). 
Figure 6: Investigations Closed

\begin{tabular}{|c|c|}
\hline With IOC sanctions & $33 \%$ \\
\hline With other remedial actions & $16 \%$ \\
\hline $\begin{array}{l}\text { Sanction accepted upon } \\
\text { completion of investigations }\end{array}$ & $10 \%$ \\
\hline Sanction maintained despite appeal & $7 \%$ \\
\hline Referred to BPMSD & $5 \%$ \\
\hline Other remedial measures & $4 \%$ \\
\hline Conditional non-debarment imposed & $4 \%$ \\
\hline \multicolumn{2}{|l|}{ Without remedial action } \\
\hline Unsubstantiated & $16 \%$ \\
\hline Disproven & $5 \%$ \\
\hline
\end{tabular}

BPMSD = Budget, Personnel, and Management Systems Department; $I O C=$ Integrity Oversight Committee.

Source: Asian Development Bank (Office of Anticorruption and Integrity).

\section{Remedial Actions Imposed by the Integrity Oversight Committee}

ADB presented 16 cases to the Integrity Oversight Committee (IOC), which imposed debarments on 14 firms and 19 individuals (Table 1). ${ }^{3}$

\section{Cross-Debarment}

ADB cross-debarred 272 firms and 48 individuals, and referred 13 firms and 7 individuals to other multilateral development banks for cross-debarment. ${ }^{4}$

3 The Integrity Oversight Committee (IOC), an independent committee at ADB, determines the appropriate remedial actions for integrity violations. The IOC has three members: two internal and one external. Other remedial actions consist of reprimands and cautions.

(ADB. 2015. Integrity Principles and Guidelines. Manila. para. 86.)

4 Cross Debarment. www.crossdebarment.org. 


\begin{tabular}{|l|c|c|}
\hline Remedial Actions & Firms & Individuals \\
\hline Sanctioned & $\mathbf{8 0}$ & 25 \\
\hline $\begin{array}{l}\text { Sanctions accepted upon completion } \\
\text { of investigation }\end{array}$ & 58 & 5 \\
\hline IOC-imposed & 14 & 19 \\
\hline \begin{tabular}{l} 
Temporary suspension \\
\hline Conditional non-debarment
\end{tabular} & 1 & 0 \\
\hline Reprimanded & 7 & 1 \\
\hline Cautioned & 16 & 14 \\
\hline Cross-debarred & 272 & 48 \\
\hline
\end{tabular}

IOC = Integrity Oversight Committee.

Source: Asian Development Bank (Office of Anticorruption and Integrity).

\section{Reinstatement}

$\mathrm{ADB}$ reinstated 23 firms. ${ }^{5} \mathrm{OAl}$ requires debarred entities to take corrective action and improve their internal governance before reinstatement.

\section{Temporary Suspension}

The IOC temporarily suspended one firm and extended the temporary suspension of another. Temporary suspension prevents the awarding of ADB-financed contracts to a firm or individual likely to be sanctioned.

5 ADB has reinstated 419 firms and 155 individuals since 2000. 
It is not subject to appeal. Any attempt to participate in ADB-related activity during the temporary suspension period will automatically result in a minimum debarment period of 3 years.

\section{Appeals}

In five cases, eight firms and four individuals submitted appeals in 2018. The appeals failed to meet the requirements for consideration by ADB's Sanction Appeals Committee, and were denied by the committee secretariat. ${ }^{6}$

\section{OAI Investigations Division Staff Cases}

OAl submitted three investigation reports to the Budget, Personnel, and Management Systems Department (BPMSD), which imposed disciplinary action in two cases. The third case was under assessment at the end of 2018. See Appendix A for more information about these investigations.

\section{Whistleblower Protection in OAI Investigations}

ADB protects the identity of whistleblowers and witnesses acting in good faith, to ensure that they are not subjected to retaliation. ${ }^{7}$ For integrity violations and misconduct, whistleblowers may remain anonymous or request confidentiality. In 2018, four complainants requested anonymity and no retaliation was reported to $A D B$.

Figure 7 describes the process for investigating external parties and Figure 8 describes the process for investigating ADB staff members.

6 ADB. 2015. Integrity Principles and Guidelines. Manila. para. 98.

7 ADB. 2017. Whistleblower and Witness Protection. Administrative Orders. AO 2.10. Manila. 


\section{Figure 7: Process of External Party Investigation}

(1) OAI receives an allegation of integrity violation by an external party.

Complaint closed

(2) OAl assesses the allegation. $\longrightarrow$ or referred to

(3) OAl investigates the allegation. $\longmapsto \longrightarrow \begin{aligned} & \text { Investigation } \\ & \text { closed }\end{aligned}$

(4) OAI presents its investigative findings.

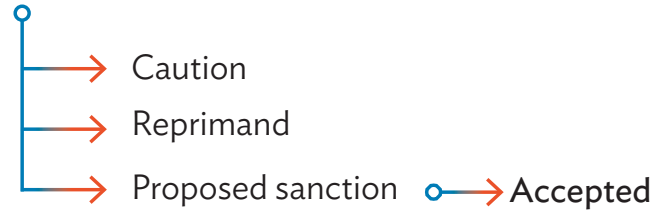

Complaint closed

(5) OAI refers the complaint to IOC.
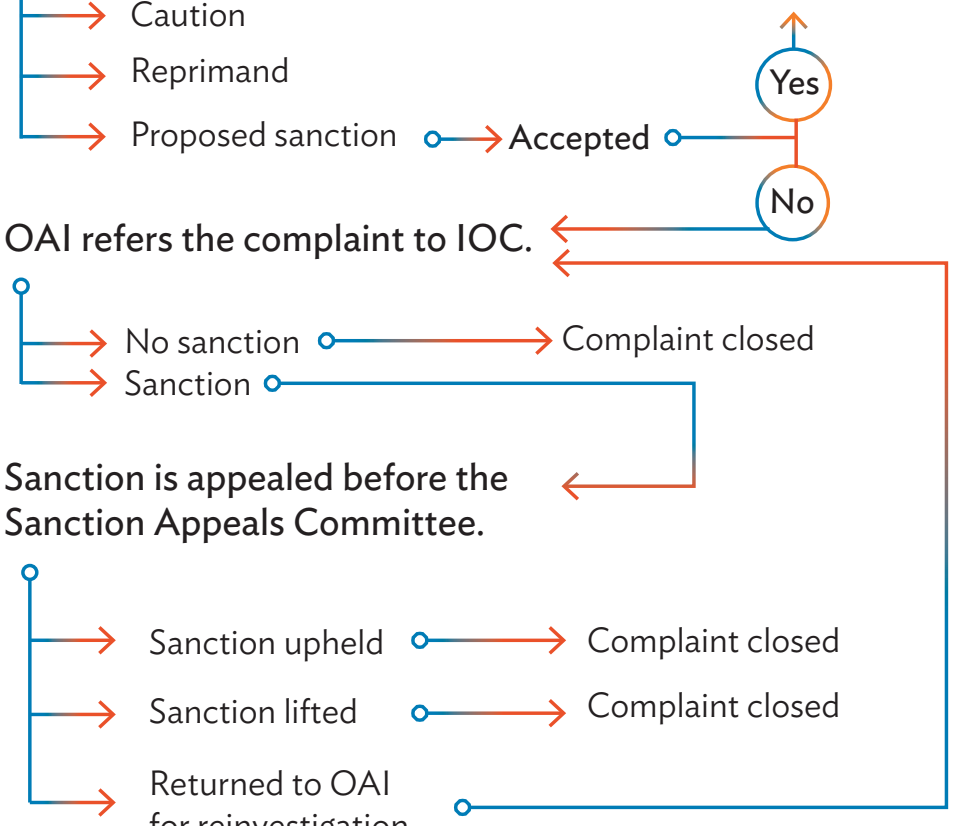

6 Sanction is appealed before the

for reinvestigation

$\mathrm{IOC}=$ Integrity Oversight Committee, OAI = Office of Anticorruption and Integrity.

Notes: This flowchart is not intended to, and does not replace, modify, supersede, or amend, ADB's Integrity Principles and Guidelines (2015). Integrity violations that the Office of Anticorruption and Integrity may investigate include corrupt, fraudulent, coercive, collusive, or obstructive practices; abuse; or conflicts of interest.

At any time during the investigation, the Office of Anticorruption and Integrity may present to the Integrity Oversight Committee a request for a temporary suspension of the party (paras. 72-78 of the 2015 Integrity Principles and Guidelines).

Source: Asian Development Bank (Office of Anticorruption and Integrity). 
1 OAl receives an allegation of integrity violation, bullying, harassment, or other staff misconduct. ${ }^{a}$

2 OAl screens the allegation.

$\longrightarrow$ Is the allegation within OAl's mandate, credible, verifiable, and material?

3

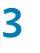

4

The OAI head, the OAI director, and/or the unit head approves the investigation plan.

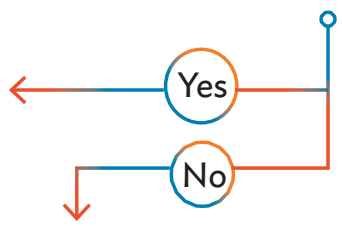

\section{OAl investigates} the allegation.

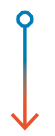

The OAI head and/or the director approves the closing report and, if appropriate, refers it to BPMSD.

Is it more likely than not that the staff violated the Anticorruption Policy or AO 2.02: Code of Conduct?
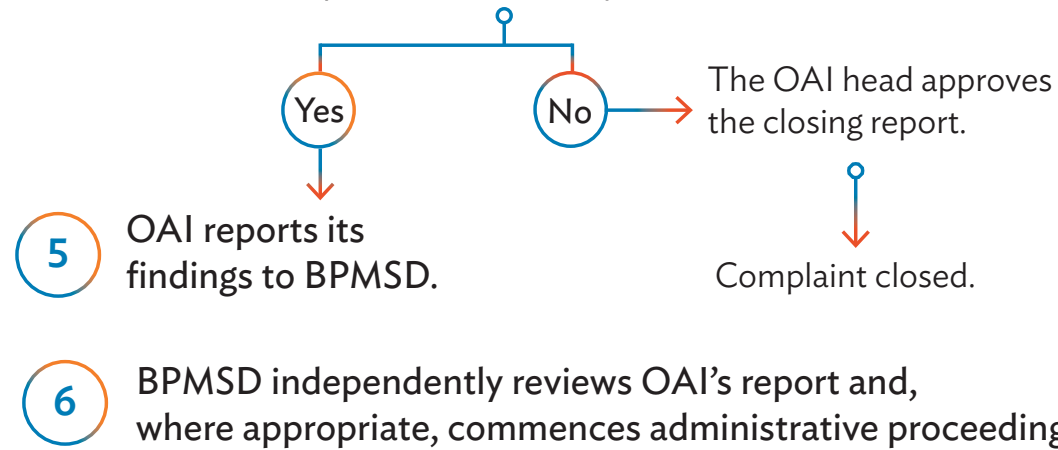

OAI reports its findings to BPMSD.<smiles>O=C1CC1</smiles>

Complaint closed.

\section{BPMSD independently reviews OAl's report and,} where appropriate, commences administrative proceedings under AO 2.04: Disciplinary Measures and Procedures.

$\mathrm{AO}=$ administrative order; BPMSD = Budget, Personnel, and Management Systems Department; $\mathrm{OAI}=$ Office of Anticorruption and Integrity.

Note: This flowchart is not intended to, and does not replace, modify, supersede, or amend, ADB's Integrity Principles and Guidelines (2015), AO 2.02 (2017), AO 2.04 (2017).

a Where the allegation refers to an integrity violation (including fraud, corruption, and abuse), the Investigations Division of OAl addresses the allegation. Where the allegation refers to misconduct other than an integrity violation, the Respectful Workplace Unit addresses the allegation.

${ }^{b}$ Where appropriate, staff may consult or be referred to the Office of the Ombudsperson by OAI. 


\section{FOSTERING A RESPECTFUL WORKPLACE}


The Respectful Workplace Unit (AIOD-RWU) was established to create and promote a respectful and professional workplace, and is nearing the end of a 2-year pilot phase. A working group is reviewing AIOD-RWU's experience to assess how ADB can best address workplace concerns after the pilot phase.

AIOD-RWU comprised three staff and three consultants in 2018 and shared in OAl's investigative and outreach resources. ${ }^{8}$ Also in 2018, $A D B$ was accepted as a member of the Ethics Network of Multilateral Organizations and participated at its 10th meeting. As a member, ADB contributes to the development of best practices in ethics and integrity. ${ }^{9}$

\section{The Respectful Workplace Unit's Visitors}

In 2018, the Respectful Workplace Unit (AIOD-RWU) received 131 visitors and opened 122 workplace matters relating to harassment, bullying, and other misconduct. This was an increase of $82 \%$ in workplace matters compared with the 2017 figure (Figure 9), which recognized AIOD-RWU as an avenue for discussing and resolving workplace matters. ${ }^{10}$

AIOD-RWU received 97 (74\%) staff visitors during the year; the rest of its visitors were consultants, contractors and/or service providers, anonymous individuals, and other persons external to $A D B$. Figures 10, 11, and 12 describe the gender, employment category, and tenure of visitors and subjects of interest.

8 One unit head, one senior integrity officer, and one associate integrity analyst as permanent staff of the unit; one international consultant and two national consultants, on an intermittent basis.

9 See the UN Secretary General's address at https://www.un.org/sg/en/content/sg/statement/ 2018-07-10/secretary-generals-message-10th-meeting-ethics-network-multilateral.

10 Visitors are those individuals who have contacted AIOD-RWU with concerns, whether in person, by telephone, or by e-mail, either to seek advice or to file a formal complaint. In 2018, the visitors consisted of 97 ADB staff, 28 external parties, and six anonymous parties. Workplace matters are concerns related to harassment, bullying, or other misconduct, which may result in advice being provided or an investigation being conducted, or both. 
"[The Respect at Work e-bulletin is] a good reminder on how to deal with challenging colleagues and be able to adapt in a dynamic environment. It struck me that if they drive me crazy, it's likely that I drive them crazy, too. Time to think of how I can also improve and not just expect them to adjust on my behalf."

-ADB staff member

Figure 9: Received Matters and Visitors (2017-2018)

2018

$12282 \%$

131

2017

67

73

Received matters (including harassment, bullying, and other misconduct)

Received visitors

Source: Asian Development Bank (Office of Anticorruption and Integrity).

Figure 10: Gender of Visitors and Subjects of Interest

\begin{tabular}{lll}
\hline \multirow{2}{*}{ Visitors } & & $61 \%$ \\
\cline { 2 - 3 } & $39 \%$ & \\
\hline
\end{tabular}

Subjects of interest

\section{$42 \%$}

\section{$58 \%$}

Female staff

Male staff

Source: Asian Development Bank (Office of Anticorruption and Integrity). 
Figure 11: Employment Category of Visitors and Subjects of Interest

AD Management /Board of Directors

- Anonymous

National staff

- Administrative staff

- International staff

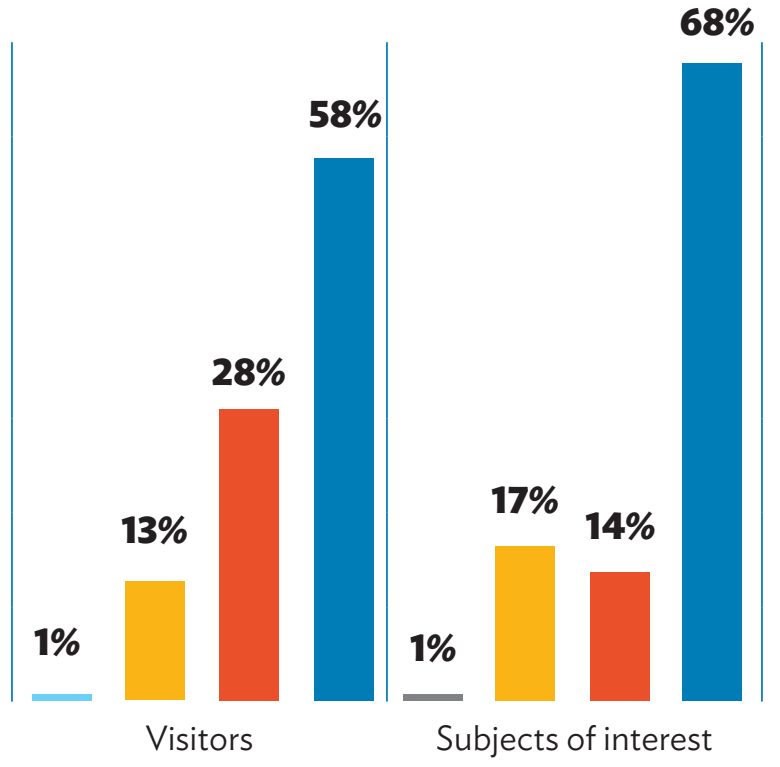

$\mathrm{ADB}=$ Asian Development Bank.

Source: Asian Development Bank (Office of Anticorruption and Integrity).

Figure 12: Tenure of Staff Visitors and Staff Subjects of Interest

\begin{tabular}{rc}
\hline Less than 1 year & $\mathbf{1 3 \%}$ \\
& $\mathbf{1 2 \%}$ \\
\hline $\begin{array}{r}1 \text { year to } \\
\text { less than } 3 \text { years }\end{array}$ & $\mathbf{1 0 \%}$ \\
\hline $\begin{array}{r}3 \text { years to } \\
\text { less than } 5 \text { years }\end{array}$ & $\mathbf{9 \%}$ \\
\hline 5 years to & $\mathbf{9 \%}$ \\
\hline less than 10 years & $\mathbf{1 9 \%}$ \\
\hline 10 years & $\mathbf{1 8 \%}$ \\
and above & \\
\hline
\end{tabular}

Visitors

Subjects of interest

Source: Asian Development Bank (Office of Anticorruption and Integrity). 


\section{Advisories and Investigations}

AIOD-RWU reviewed 177 workplace matters in 2018, which includes 55 matters from the previous year."

\section{Advisories}

AIOD-RWU provided 125 advisories, including 35 from 2017. Of the advisories, $89(71 \%)$ were closed, while the others were being monitored at the end of 2018. Bullying and harassment accounted for 72 (58\%) of these advisories.

\section{Investigations}

AIOD-RWU investigated 52 cases, 33 (63\%) of which pertained to allegations of bullying and harassment. Seven cases were submitted to BPMSD, which issued a written censure in one case and written reprimands in two cases, and will determine appropriate remedial action for the rest. ${ }^{12}$ AIOD-RWU closed 28 cases, as there was insufficient evidence to determine whether the Code of Conduct had been breached. Eighteen investigations were open at year-end. See Appendix B for more information about these investigations.

1 Some staff chose not to have their matters investigated, while others were assessed by AIOD-RWU as not requiring investigation.

12 Oral or written reprimands are not considered a disciplinary measure. Written censure, on the other hand, is a disciplinary measure, which is maintained in the staff's personnel file permanently or for such length of time as BPMSD determines appropriate. 
ASSESSING

AND MANAGING

PROJECT INTEGRITY

RISKS 


\section{Project Procurement-Related Reviews}

In 2018, OAl conducted follow-up reviews of five projects in Mongolia, Papua New Guinea, Sri Lanka, and Timor-Leste that had undergone project procurement-related reviews (PPRRs) in 2016 and 2017. ${ }^{13}$ It carried out a full PPRR of a water sector project in Viet Nam (Table 2).

Table 2: Profile of Projects Reviewed and Reports Issued

\begin{tabular}{|l|c|c|}
\hline Item & Number & Value \\
\hline $\begin{array}{l}\text { Reviews conducted } \\
\quad \begin{array}{l}1 \text { project procurement-related review } \\
5 \text { follow-up reviews }\end{array}\end{array}$ & 6 & $\$ 1.7$ billion \\
\hline Contracts reviewed & 53 & $\$ 462$ million \\
\hline Withdrawal applications reviewed & 185 & $\$ 171$ million
\end{tabular}

Source: Asian Development Bank (Office of Anticorruption and Integrity).

These reviews also covered 54 bids, 16 proposals, and 11 expressions of interest.

OAl's Review and Outreach Unit (AIOD-RU) issued three reports-two on the follow-up reviews in Sri Lanka and Timor-Leste, and a report on the follow-up review of an India project that began in November 2017.

OAI conducts PPRRs of active and ongoing projects to recommend internal control improvements that will mitigate or eliminate opportunities for integrity violations. Follow-up reviews are done to evaluate the implementation status of the PPRR recommendations and enhance their impact on project implementation. ${ }^{14}$

\footnotetext{
13 Two follow-up reviews were done in Papua New Guinea.

14 These follow-up reviews take place at least 6 months after the issuance of the PPRR report.
} 
These follow-up reviews have received positive feedback from project stakeholders.

$\mathrm{OAI}$ also assists executing and implementing agencies in addressing pending recommendations. The executing and implementing agencies of the projects reviewed in India, Mongolia, and Timor-Leste had implemented the majority of the PPRR recommendations.

India. The high uptake of PPRR recommendations (80\% of the total) was complemented by affirmative stakeholder perspectives on the PPRR. The executing agency highlighted its collaboration with ADB and demonstrated concrete gains in OAl's anticorruption awareness initiatives.

"We made sure that whatever had been observed from your end served as a compliance list for us, as a checklist for us, so we could make sure that nothing went wrong in this project."

-Rahul Goswami

Deputy General Manager (Town Planning) Jaipur Metro Rail Corporation

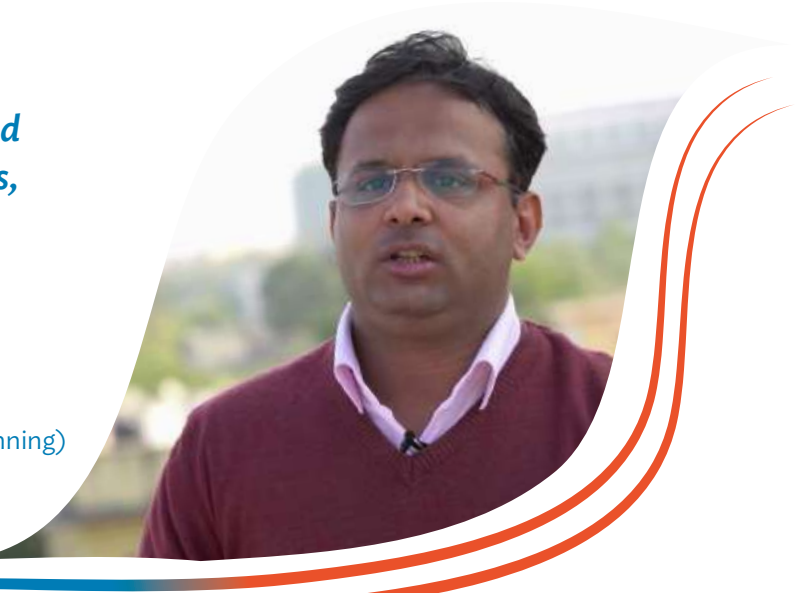

Mongolia. With assistance from the ADB resident mission, the executing agency trained bid evaluation committee members in ADB's procurement guidelines. It also developed an annual monitoring plan and visited project sites as part of the agency's close monitoring activities. Altogether, these initiatives helped the executing agency fully implement most (91\%) of the PPRR recommendations. 
"ADB has a very important role and participation in the main sectors of Mongolia, including health. A number of recommendations provided during the 2016 PPRR have proven that independent inspection and evaluation has a very important contribution to the project. A mission is working now to provide independent inspection and recommendations. I wish it every success."

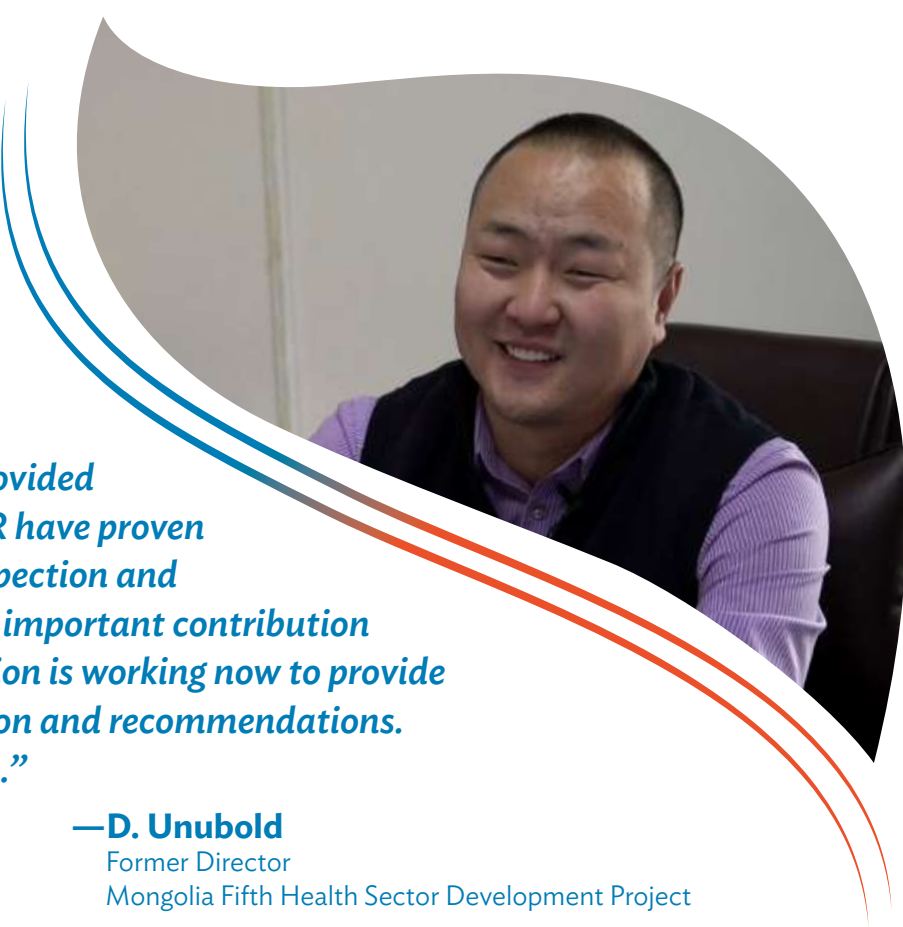

Timor-Leste. Sixty-nine percent of the PPRR recommendations were implemented except those requiring major actions from the government, which could not be immediately addressed. The review team, as an interim solution, proposed changes in the contract provisions, which the key project staff positively welcomed.

Papua New Guinea. Several recommendations from the 2016 PPRRs remained either not implemented or partially implemented. OAI assisted the executing agency to develop action plans to implement the key pending recommendations.

The support of $A D B$ resident missions played a significant role in addressing the PPRR recommendations. The remaining recommendations that are at various stages of implementation highlight the continuing need for ADB's assistance in strengthening the project management capacity of executing and implementing agencies. 
"PPRR has had a very positive impact.

At the time the mission came, we identified

some issues that were not at a very serious stage,

at the moment, but without the mission, it might have evolved in a different direction and delayed the proper implementation and objectives of the project.

It was also a wake-up call for the officials of the Ministry of Health, reminding them that they have to pay more attention to important details to ensure full compliance."

-Yolanda Fernandez Lommen Country Director Mongolia Resident Mission

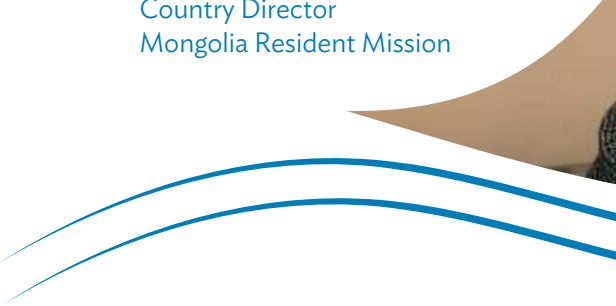

\section{Integrity Risk Management Reviews}

OAI conducts integrity risk management reviews of projects in ADB's pipeline to identify fraud and corruption risks, propose risk-mitigating measures, and determine the need for further integrity due diligence. OAI applies lessons learned from prior PPRRs relating to vulnerabilities in procurement and financial management that the regional departments need to be aware of.

This assists in the appropriate identification of integrity risk areas and the reassessment of risk ratings in the Risk Assessment and Management Plan. Compared with the 2017 total, OAI received $43 \%$ more requests for integrity risk management reviews of 62 pre-approval project documents across 57 projects in 2018 (Table 3). 
Table 3: Pre-approval Project Documents Reviewed

\begin{tabular}{l|c|c|}
\hline ADB Department & No. of Projects & No. of Documents \\
\hline East Asia & 2 & 2 \\
\hline Central and West Asia & 6 & 7 \\
\hline Southeast Asia & 4 & 4 \\
\hline South Asia & 8 & 9 \\
\hline Pacific & 21 & 23 \\
\hline Other departments & & 17 \\
\hline Total & 16 & 62 \\
\hline
\end{tabular}

$\mathrm{ADB}=$ Asian Development Bank.

a Private Sector Operations Department, Office of Cofinancing Operations, Office of Public-Private Partnership, and Sustainable Development and Climate Change Department, which requested comments on technical assistance reports and concept papers.

Source: Asian Development Bank (Office of Anticorruption and Integrity). 


\section{Integrity Due Diligence}

The Due Diligence Unit (AIOD-DU) reviewed 871 entities in 2018, 12\% more than the 777 entities reviewed in 2017 (Table 4). Fourteen entities were rated as having significant integrity-related risk. OAI collaborated with the project teams to ensure that integrity-related risks were disclosed and mitigating measures were implemented.

\section{Table 4: Integrity Due Diligence Reviews}

\begin{tabular}{|l|c|}
\hline Item & Number/Amount \\
\hline Entities reviewed for integrity due diligence & $\mathbf{8 7 1}$ \\
\hline Preemployment screenings & $\mathbf{6 5 1}$ \\
\hline Know-your-customer requests & $\mathbf{7 0}$ \\
\hline
\end{tabular}

Source: Asian Development Bank (Office of Anticorruption and Integrity).

These entities comprised of

- 422 entities reviewed at the request of the Private Sector Operations Department (PSOD), on nonsovereign operations;

- 368 entities reviewed at the request of other departments, for ADB's annual meeting and other sponsored events, local banking relationships, payments to consultants, and technical assistance projects; and

- 81 entities reviewed at the request of regional departments on sovereign operations. 
The Procurement, Portfolio, and Financial Management Department (PPFD) and $O A I$ launched a pilot program that introduced an integrity due diligence process for ADB-administered consulting services. This process is intended to ensure the existence of adequate and systematic controls for identifying and addressing potential integrity and reputational risks in recruiting consultants. Forty-six consultants-firms as well as individuals - were reviewed during the pilot program. OAI shared with PPFD its assessments from the reviews and provided recommendations for four consulting engagements that presented significant risk factors.

\section{Preemployment Screening}

OAI continued to support BPMSD by conducting 651 employment checks for shortlisted applicants, 37\% more than in 2017. OAI raised conflict-of-interest and integrity concerns about nine candidates with BPMSD. As a result, three candidates were not hired and one application was withdrawn.

\section{Know-Your-Customer Requests}

OAl responded to 70 know-your-customer requests as part of the counterparties' onboarding of ADB or annual review processes. OAl's responses facilitated the conduct of the counterparties' review and fulfilled their compliance requirements for dealing with ADB. 


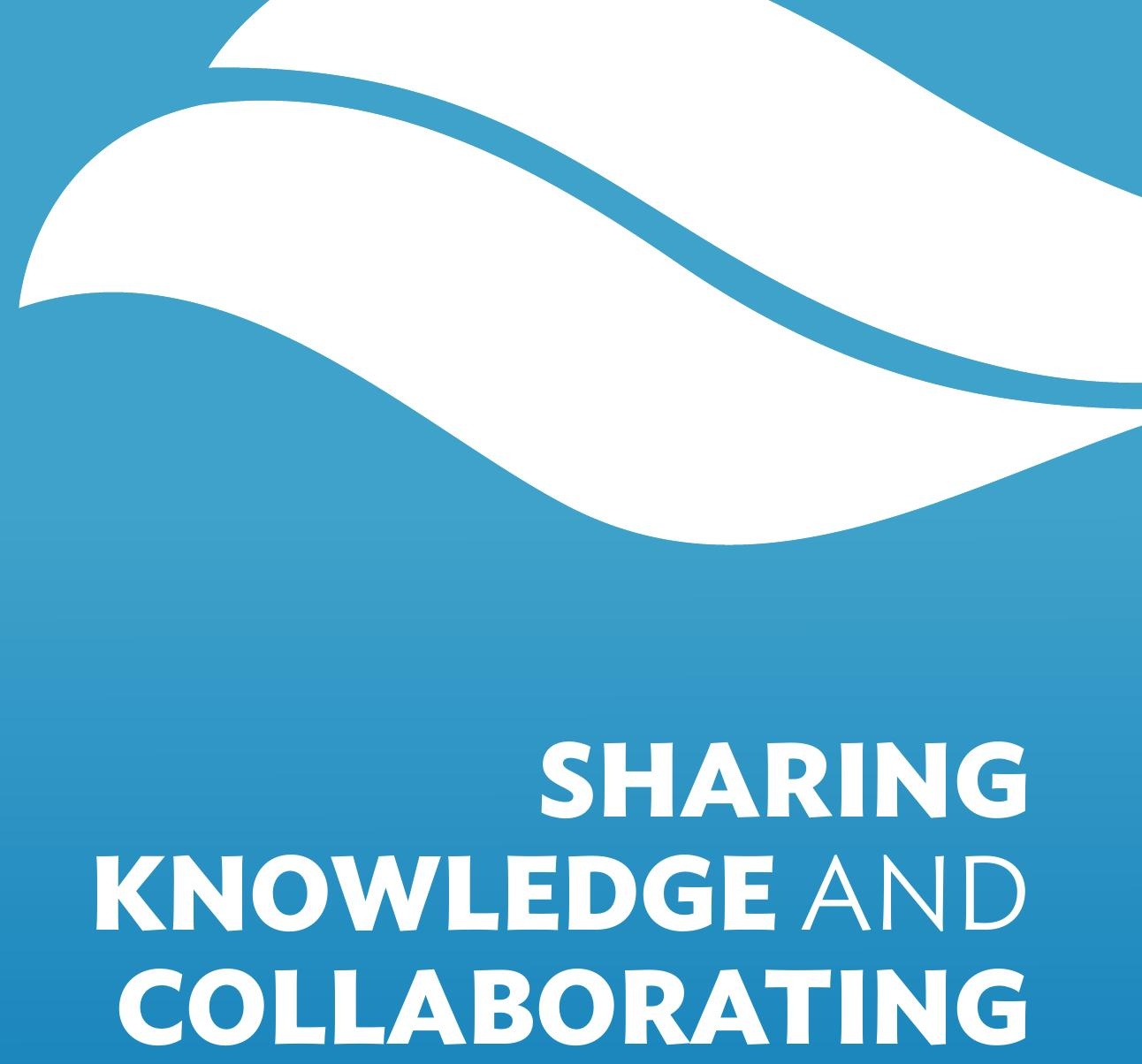

WITH STAKEHOLDERS 
Working with its stakeholders in 2018, OAI continued to promote collaboration and exchange knowledge to combat integrity violations. $\mathrm{OAl}$ increased its online presence and the number of face-to-face learning events, in the process building awareness among ADB staff and developing member country (DMC) officials and enhancing their capacity.

\section{Knowledge-Sharing Events}

OAl conducted 118 knowledge-sharing sessions for over 4,000 participants (Table 5) in 22 DMCs. These sessions ranged from hour-long awareness-raising briefing sessions to 2-day learning programs.

Table 5: 2018 OAI Learning Sessions and Participants

\begin{tabular}{|l|c|c|c|}
\hline Item & $\begin{array}{c}\text { DMC } \\
\text { Development Partners }\end{array}$ & $\begin{array}{c}\text { ADB Staff } \\
\text { and Consultants }\end{array}$ & Total \\
\hline $\begin{array}{l}\text { Sessions } \\
\text { conducted }\end{array}$ & $\mathbf{7 3}$ & $\mathbf{4 5}$ & 118 \\
\hline $\begin{array}{l}\text { Participants } \\
\text { reached }\end{array}$ & 3,042 & 1,556 & 4,598 \\
\hline
\end{tabular}

$A D B=$ Asian Development Bank; DMC = developing member country; $O A I=$ Office of Anticorruption and Integrity.

Source: Asian Development Bank (Office of Anticorruption and Integrity).

Outreach. Over 65\% $(3,042)$ of the beneficiaries of OAl's outreach from 73 learning sessions were DMCs and development partners.

These outreach events included:

- The Enhanced Anti-Money Laundering and Financial Crime Tools and Techniques Symposium in Manila in June 2018. It was organized by OAl, in partnership with the Association of Certified Anti-Money Laundering Specialists and their Philippine Chapter. 
- At the invitation of the Ministry of Finance of the People's Republic of China (PRC), a presentation on ADB's anticorruption policy and practices to over 160 staff from provincial finance departments at the Training Course on Anticorruption in Zhenjiang in December.

Internal capacity development. Over 1,500 ADB staff and consultants from headquarters and resident missions participated in 45 face-to-face training sessions regarding

- ADB's Anticorruption Policy,

- financial due diligence for ADB projects,

- fraud detection and prevention,

- integrity and respect at work,

- integrity due diligence,

- proactive integrity reviews in ADB projects,

- due diligence and integrity (under ADB's Project Design and Management Program), and

- respect in the workplace.

Over $68 \%$ of sessions for ADB staff and consultants were on Respect in the Workplace.

Ninety-eight percent of ADB staff completed OAl's e-learning course, consisting of two modules: Anticorruption and Integrity, and Respect at Work.

OAI also reached out to staff through more than 120 posts on ADB Today and Yammer. ${ }^{15}$

15 ADB Today is ADB's daily e-bulletin, while Yammer is a social media platform for ADB users. These internal advisories cover cross-debarred entities, entities sanctioned by the Integrity Oversight Committee, OAl events, online courses, and sharing of OAI knowledge products. 
"iACT to fight corruption!" This campaign remains ADB's centerpiece anticorruption and integrity initiative. IACT learning and awarenessraising events reached over 350 participants at the following:

- ADB Business Opportunities Fair in Manila in March;

- Anticorruption \& Integrity Training for the Philippine Department of Foreign Affairs-Office of Consular Affairs, in April;

- Lecture on ADB's anticorruption and integrity efforts, at the Ateneo de Manila University School of Governance in June;

- How to Catch a Crook: The Role of Civic Engagement and Open Government (an ADB brown-bag session), in September; and

- 2018 International Anti-Corruption Day celebration in December.

The annual iACT exhibit featured a bespoke arcade game, iPLAY iACT, which tested players' knowledge of integrity violations. Three iACT game booths were installed at headquarters and an online link was provided to ADB staff, consultants, contractors, and service providers in ADB offices. The month-long iPLAY iACT initiative drew 1,152 players, who played the game more than 3,700 times.

Working against the clock, players answered as many questions as they could, improving their scores with each correct answer.

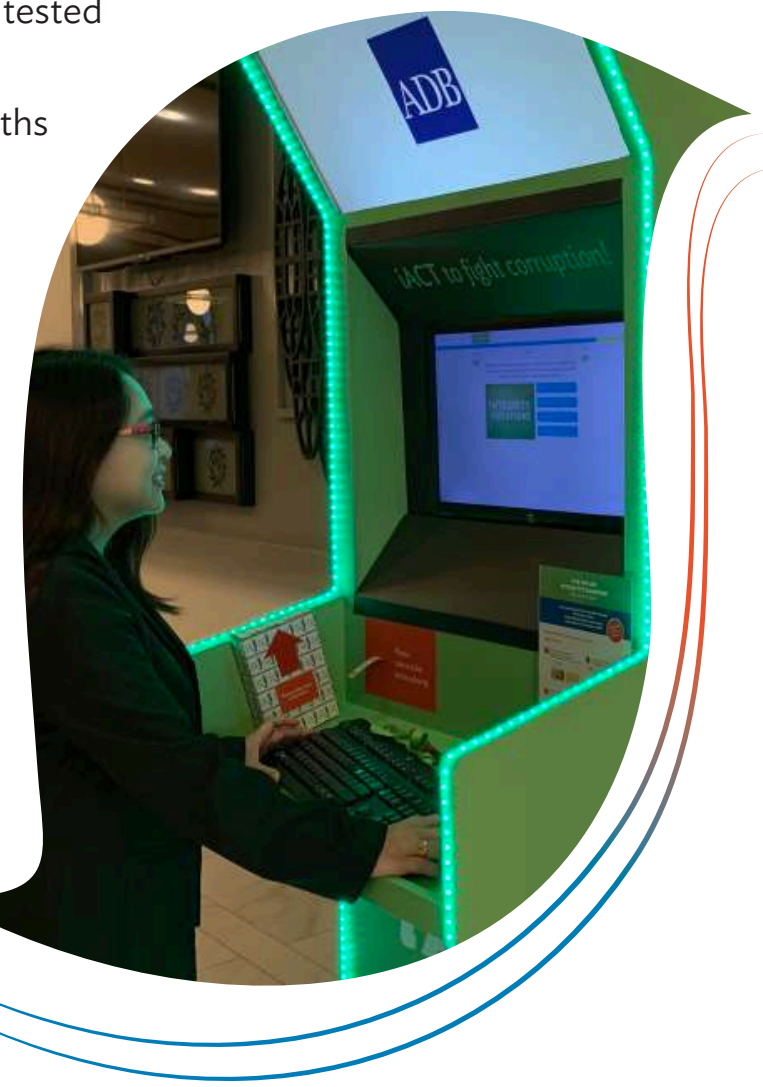




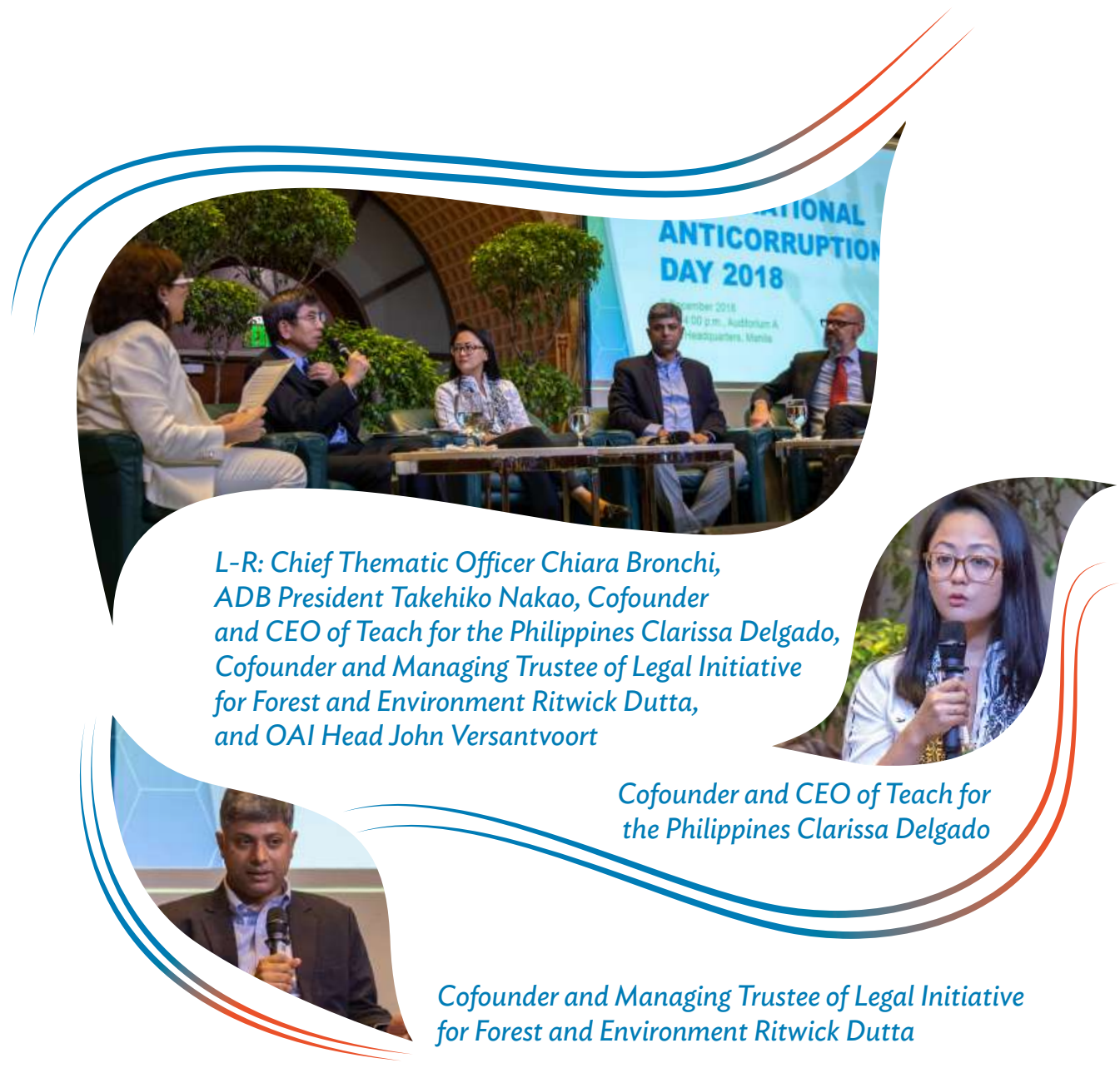

The "iACT to fight corruption!" campaign culminated in the celebration of International Anti-Corruption Day in December 2018. ADB called for efforts to fight corruption and improve governance, particularly in education and environmental management, two critical areas for securing a resilient and sustainable future for Asia and the Pacific.

Cofounder and Chief Executive Officer of Teach for the Philippines Clarissa Delgado, and Cofounder and Managing Trustee of Legal Initiative for Forest and Environment Ritwick Dutta delivered keynote speeches at the event. Ms. Delgado stressed the important role teachers play in the fight against corruption by leading by example and imparting values of integrity to their students. Mr. Dutta highlighted the key role of civil society and courts in ensuring that enforcement agencies implement the law. 


\section{Collaboration}

Integrity advisories. $\mathrm{OAI}$ also continued to support $\mathrm{ADB}$ operations and enhance information exchange with internal and external stakeholders. OAI rendered a total of 717 integrity advisories on requests relating to cofinancing and other partnerships; conflict of interest; contract variations for sanctioned entities; and general advisories on cross-debarment, eligibility of sanctioned entities, and anticorruption clauses in project documents, agreements, and contracts, among other topics.

Anti-Corruption Initiative for Asia and the Pacific. OAI continued to work with the Organisation for Economic Co-operation and Development (OECD) in managing the Anti-Corruption Initiative for Asia and the Pacific. ${ }^{16}$ The largest anticorruption network in the world, the initiative supports DMCs in implementing the United Nations Convention against Corruption through capacity development, mutual support, and exchange of expertise and knowledge products. ${ }^{17}$

OAl led a 3-month evaluation of the initiative's relevance and effectiveness. According to the findings, the initiative met member expectations and complemented other anticorruption initiatives and networks in the region. The study recommended that the initiative continue with its capacity-building and policy review activities and build on its responsiveness by orienting itself toward results and partnerships.

In November, 50 anti-corruption initiative members from over 20 countries attended the Public Integrity Network Meeting on Preventing Corruption in Public Procurement, organized by ADB and held in Astana, Kazakhstan.

${ }^{16}$ Formerly known as the ADB-Organisation for Economic Co-operation and Development Anticorruption Initiative for Asia and the Pacific

17 The 31 member countries and jurisdictions of the initiative are Afghanistan; Australia; Bangladesh; Bhutan; Cambodia; the Cook Islands; Fiji; Hong Kong, China; India; Indonesia; Japan; Kazakhstan; the Kyrgyz Republic; Macau, China; Malaysia; Mongolia; Nepal; Pakistan; Palau; Papua New Guinea; the People's Republic of China; the Philippines; the Republic of Korea; Samoa; Singapore; Solomon Islands; Sri Lanka; Thailand; Timor-Leste; Vanuatu; and Viet Nam. 
The meeting was called to promote discussion about combating corruption in public procurement and enhance the relevant skills.

\section{Initiatives to combat sexual exploitation and abuse. OAI played}

a key role in collating and presenting ADB's efforts to address sexual harassment and misconduct in the workplace. At the April 2018 meeting hosted by the Department for International Development of the United Kingdom (DFID) and the Netherlands Minister for Foreign Trade and Development Cooperation, ADB and nine other international financial institutions (IFIs) released a Joint Statement on Continuous Advancement of Standards to Prevent Sexual Harassment, Abuse, and Exploitation, committing themselves to the prevention, protection, and reporting of sexual exploitation, abuse, and harassment. ${ }^{18}$

The IFls reaffirmed their commitment through the following seven principles: (i) fostering a culture of respect and high standards of ethical behavior across institutions; (ii) establishing and maintaining standards aimed at prevention; (iii) providing a safe and trusted environment for those affected; (iv) providing protection for those affected as well as for whistleblowers within institutions, and taking measures against retaliation; ( $v$ ) maintaining robust policy frameworks and institutional mechanisms to address and handle incidents and/or allegations; (vi) providing effective training programs for staff; and (vii) supporting clients in developing and implementing policies and mechanisms to address sexual harassment, abuse, and exploitation.

ADB tracked its implementation of each of the seven principles contained in the statement and provided an update of the progress and measures undertaken as of September 2018. This was consolidated with the updates from the other multilateral development banks by the European Bank for Reconstruction and Development, and a joint IFI update was prepared.

18 The IFI hosts of the meeting were ADB, the African Development Bank, the Asian Infrastructure Investment Bank, the European Bank for Reconstruction and Development, the European Investment Bank, the Inter-American Development Bank, the International Finance Corporation, the International Fund for Agricultural Development, the International Monetary Fund, and the World Bank. 
This joint IFI update was endorsed by the multilateral development bank heads at the World Bank meeting in Bali, Indonesia, in early October 2018 and was then presented at the DFID Safeguarding Summit on 18 October 2018 in London.

Tax integrity initiatives. Under its Tax Integrity Policy, ${ }^{19}$ ADB is committed to increasing its support for tax integrity initiatives by building on and developing the technical assistance program it has undertaken, to (i) assist DMCs in promoting their domestic resource mobilization by enhancing their ability to protect themselves against tax evasion and base erosion and profit shifting (BEPS); (ii) develop the capacity of DMCs to become members of the Global Forum and participate in its work; and (iii) support DMC participation in BEPS initiatives.

OAI, with the Sustainable Development and Climate Change Department and other departments, continues to collaborate with DMCs and stakeholders. The partnership with the Global Forum on Transparency and Exchange of Information for Tax Purposes leverages ADB's relationships with national governments and the Global Forum's technical expertise in international tax transparency standards.

ADB further strengthened international and regional cooperation on tax matters. It engaged with the Asia-Pacific Economic Cooperation (APEC) and regional organizations like the Pacific Islands Tax Administration Association, Intra-European Organization of Tax Administrations, ASEAN Forum on Taxation, and Study Group on Asian Tax Administration and Research, among others.

19 In December 2016, ADB adopted an amendment to the Anticorruption Policy (1998, as amended to date)-Enhancing the Role of the Asian Development Bank in Relation to Tax Integrity (the tax integrity policy). ADB. 2016. Anticorruption Policy: Enhancing the Role of the Asian Development Bank in Relation to Tax Integrity. Manila. 


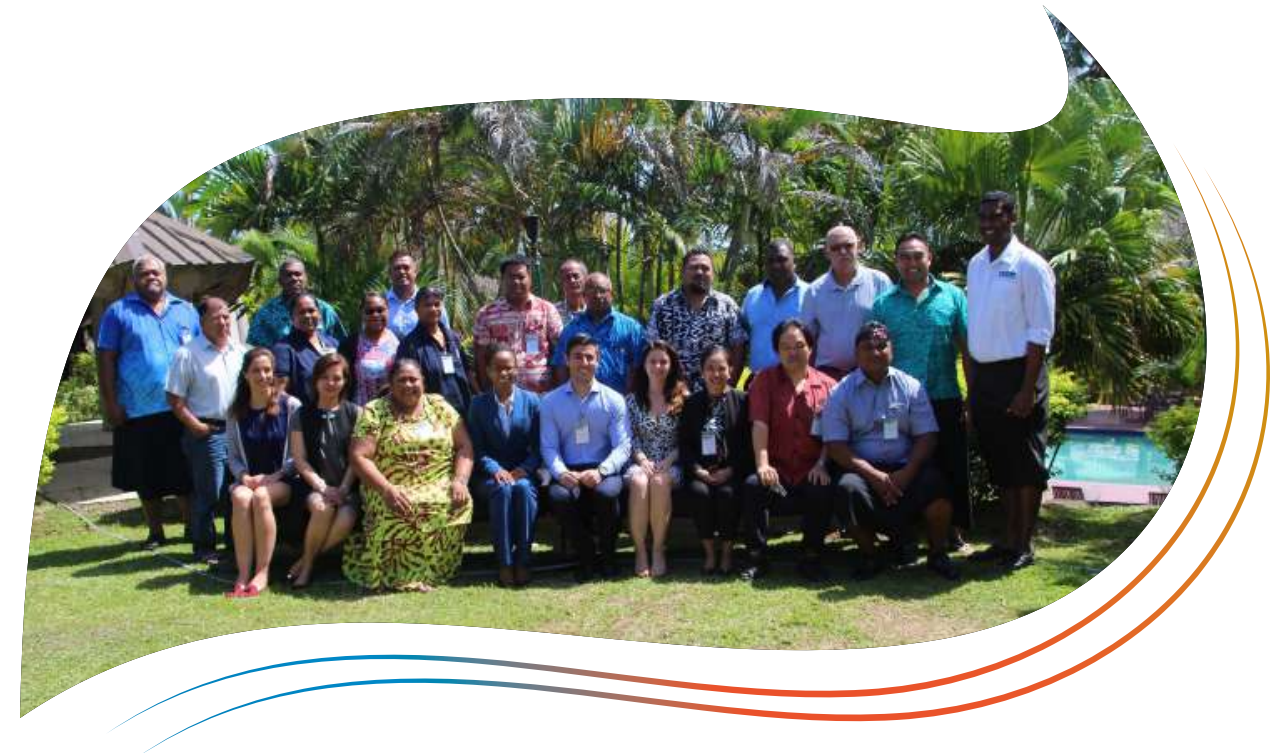

Tax auditors from 12 Pacific DMCs attended The Last Mile Seminar: Effective Exchange of Information on Request from an Auditors' Perspective. The seminar was co-organized by ADB, Global Forum on Transparency and Exchange of Information for Tax Purposes and Pacific Islands Tax Administrators Association and was held in Novotel Nadi Hotel in Fiji on 10-12 April 2018.

Tax Integrity Policy implementation review. An information paper on the review of the implementation of ADB's Tax Integrity Policy in December 2018 was circulated to the ADB Board of Directors. This followed the review conducted by an independent tax expert, who assessed ADB's implementation efforts at the country, project, and institutional levels. On its capacity-building support for tax integrity, the tax review concluded that $A D B$ had (i) engaged well-qualified tax experts to undertake the initiatives at the country level; (ii) adopted a coherent strategy to ensure that its initiatives were correctly focused; (iii) provided assistance in a steady and professional manner, taking into account the needs of DMCs and the contributions of other stakeholders; and (iv) collaborated with these stakeholders in identifying priorities, avoiding duplication, and leveraging resources. 
19th Conference of International Investigators. In October, OAl collaborated with the Green Climate Fund in organizing the 19th Conference of International Investigators in Songdo, Republic of Korea. OAl benefited from the exchange of investigative practices and challenges with peer institutions. At the conference, OAI

- conducted training sessions in practical approaches to project integrity reviews and investigations into workplace harassment;

- participated in a panel discussion on fostering a respectful workplace to address harassment, and a workshop on the challenges and successes of integrity compliance programs; and

- moderated a panel discussion on evolving policies and best practices in witness and whistleblower protection.

\section{World Bank framework agreement for alternative procurement}

arrangements. OAI supported PPFD in negotiations with the World Bank to establish a framework agreement that would facilitate the use of alternative procurement arrangements. A key feature of ADB's new procurement framework, alternative procurement arrangements will facilitate more efficient implementation of cofinanced projects.

Meetings of international organizations. In October, OAI hosted the second Heads of Integrity meeting in Songdo, on the sidelines of the Green Climate Fund's Conference of International Investigators. $A D B$, the African Development Bank, the European Investment Bank, and the European Bank for Reconstruction and Development agreed on a common definition of obstructive practice and the guidelines for referral to national authorities. OAI is updating ADB's guidelines and procedures to integrate these recent discussions. 
Representing ADB, OAI joined its counterparts in the following international anticorruption and integrity meetings:

- Private Sector Integrity Meeting and Heads of IDD Meeting, April 2018, hosted by the African Development Bank in Abidjan. OAI presented three sessions on integrity due diligence, anti-money laundering and countering the financing of terrorism, and private equity funds. OAI will host the next meeting in Manila in April 2019.

- Heads of Integrity Meeting, June 2018, hosted by the World Bank in Washington, DC.

- The 10th Meeting of the Ethics Network of Multilateral Organizations, July 2018, in New York.

- International Finance Corporation symposium on tax integrity, September 2018, in Washington, DC.

- International Anti-Corruption Conference, October 2018, in Copenhagen.

- The 4th Meeting of the International Corruption Hunters Alliance, October 2018, in Copenhagen.

- The 3rd European Investment Bank Anti-Corruption Conference, December 2018, in Luxembourg. One of the panel discussions was on proactive investigation. 


\section{Knowledge Products}

OAl published the Asset Inspection for Project Integrity: A Reference Guide for Executing and/or Implementing Agencies, providing a practical framework for asset inspection in ADB-financed projects.

This guide helps in identifying integrity risks and verifying that project funds are used for their intended purposes and beneficiaries. It provides checklists for the preparation and inspection of goods and works-what to look out for, and the types of inspected project output.

OAI produced two learning videos that highlighted measures taken to protect development projects from integrity violations.

The video ADB Anticorruption Policy Explainer: Protecting Development

Projects from Corruption was popular on social media in 2018, racking up over 70,000 views, reactions, and shares across Facebook, YouTube, Linkedln, and Vimeo.

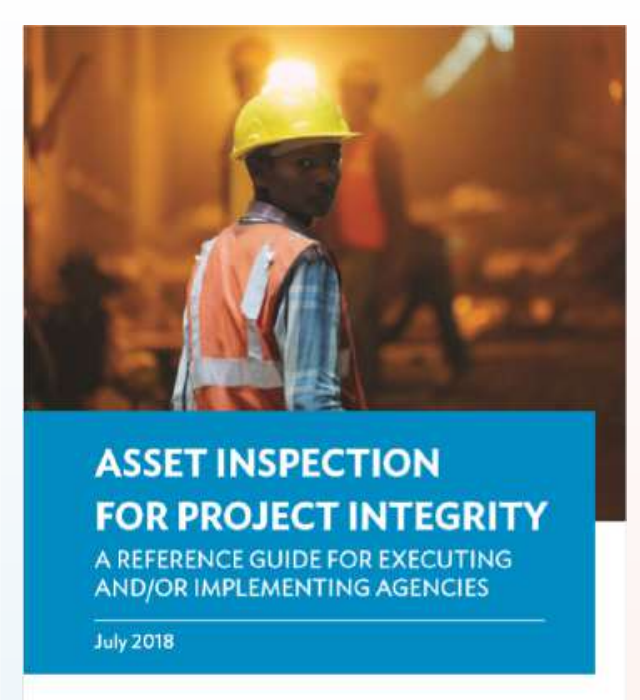

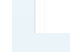
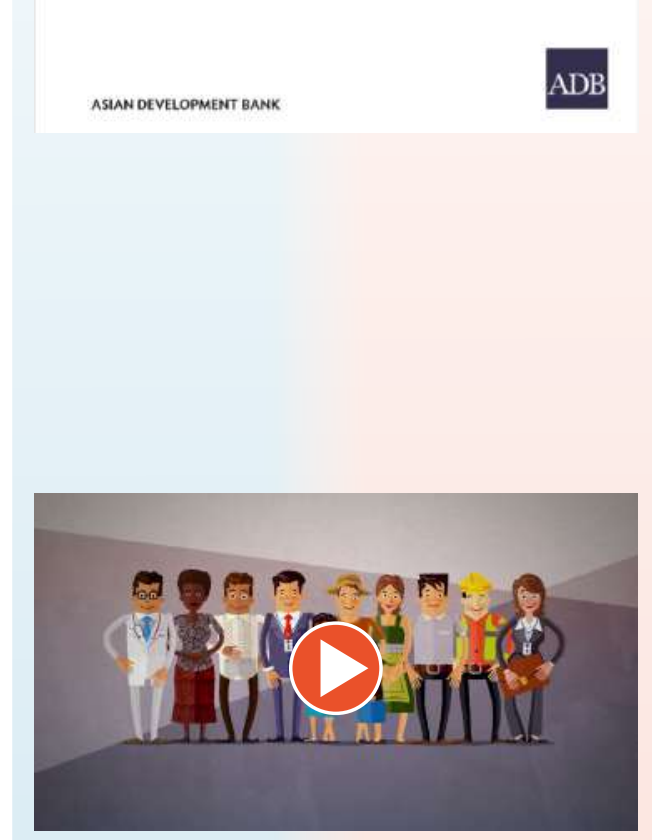
In Fostering Collaboration and

Commitment: ADB's PPRR of

Jaipur Metro Rail Corporation,

Jaipur Metro Rail Corporation

officials provided client-based

feedback on how OAl's recently

concluded project procurement-

related and follow-up reviews had

enhanced project implementation.

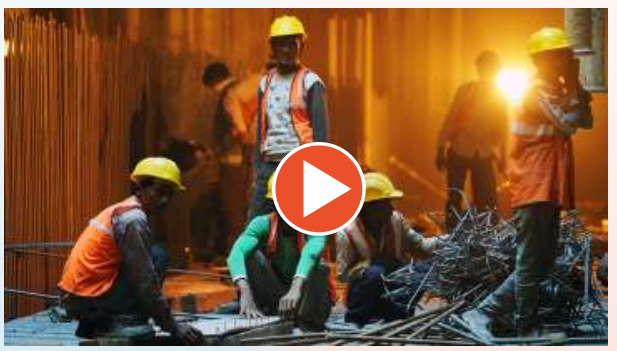

The corporation, one of the implementing agencies for the

ADB-financed \$259 million Jaipur Metro Rail Line 1-Phase B Project, handles day-to-day project execution, supervision, and management.

To expand its online reach, OAI maintained its webpage, Facebook, and Twitter accounts, as well as the dedicated intranet webpage for ADB staff which contains information about OAI operations and references.

OAl distributed four issues of the quarterly Integrity e-Bulletin to its 3,867 subscribers, and 12 issues of the monthly Respect at Work bulletin, which provides guidance on respectful and professional workplace behavior.

AIOD-RWU created, displayed, and distributed promotional materials including posters, table toppers, and informational videos.

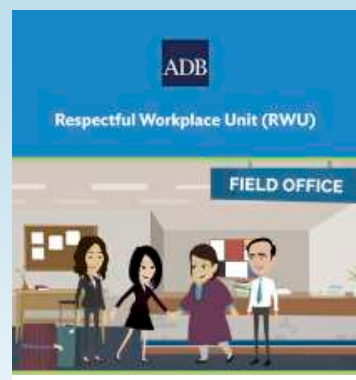

Show respect to your mission team and field office colleagues.

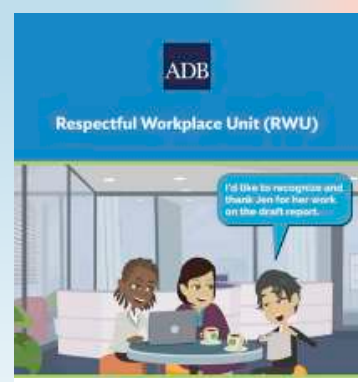

Show respect. Recognize the work that goes unnoticed!

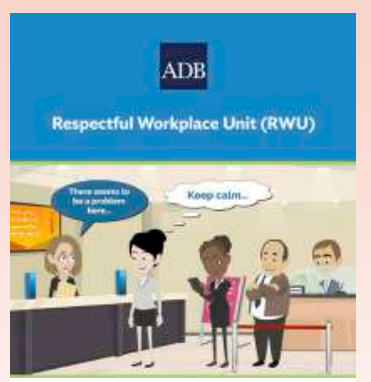

Engage respectfully at work and in ADB's wider communities. 


\section{Regional Technical Assistance Projects}

\section{TA 8176-REG: Prevention and Detection of Fraud and Corruption}

Milestones. OAl expanded the geographic reach of the TA project and jointly led two financial auditing regional workshops in Nanjing, PRC (with the National Audit Office and the PRC Resident Mission), and in Singapore (with the Southeast Asia Department).

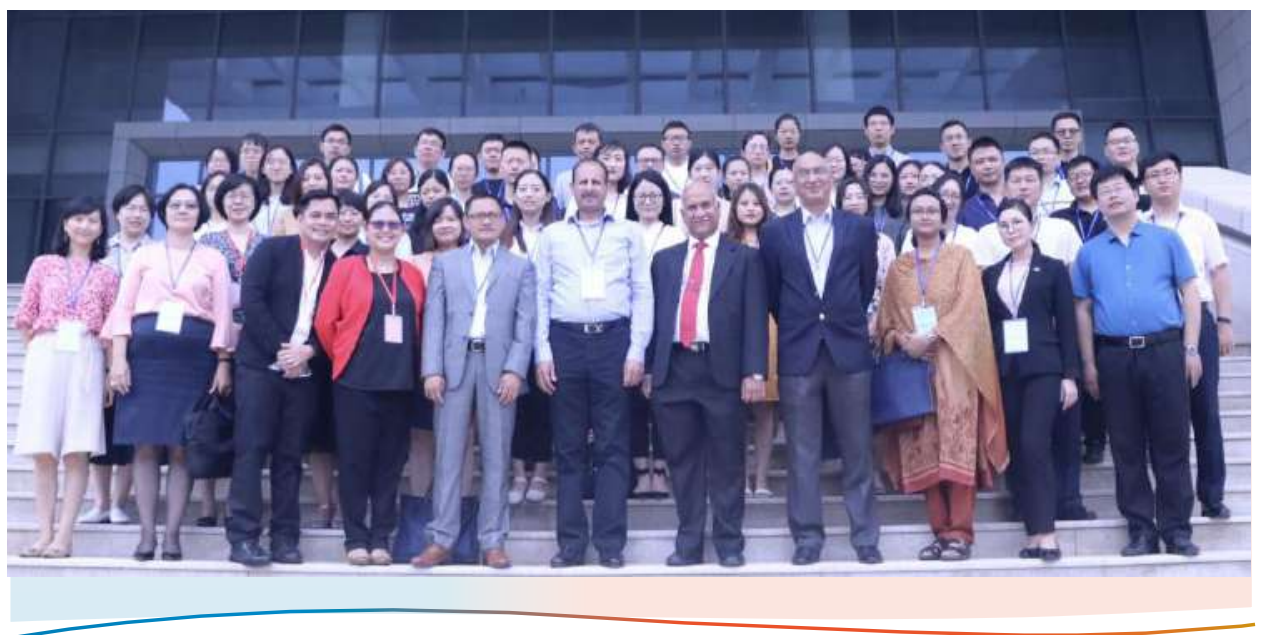

Support for DMCs to prevent and detect fraud and corruption. Participants from the supreme audit institutions of Bangladesh, Bhutan, Mongolia, Nepal, Pakistan, the People's Republic of China, and Sri Lanka came together in September 2018 at the Nanjing Audit University, Jiangsu Province, PRC to exchange lessons learned and experience in preventing and detecting fraud and corruption.

Participants. These two workshops were attended by 83 officials from 15 DMCs-Bangladesh, Bhutan, Cambodia, Indonesia, the Lao People's Democratic Republic, Malaysia, Myanmar, Mongolia, Nepal, Pakistan, the People's Republic of China, the Philippines, Sri Lanka, Thailand, and Viet Nam. 


\section{TA 8609-REG: Enhancing Integrity and Anticorruption Awareness in ADB Projects}

Milestones. Seven anticorruption seminars were held in seven DMCs -Afghanistan, Bangladesh, India, the Kyrgyz Republic, Papua New Guinea, the People's Republic of China, and Uzbekistan.

Participants. The participants consisted of 375 representatives from the government, mainly from executing and implementing agencies, the private sector (consultants, contractors, and suppliers), and international and local civil society organizations, including ADB stakeholders and partners.

\section{TA 8873-REG: Understanding and Arresting Corruption in ADB-Financed Activities}

Milestones. Tools, including country and/or sector integrity risk profiles, are being developed to help executing agencies and regional departments assess integrity risks at the project design stage and develop measures to mitigate these risks during project implementation.

\section{TA 9287-REG: Developing Anti-Mondey Laundering and Combating the Financing of Terrorism (AML/CFT) Approaches, Methodologies, and Controls}

Milestones. OAI continued working with Bhutan, Mongolia, Papua New Guinea, and the Philippines to strengthen anti-money laundering/combating the financing of terrorism (AML/CFT) regulatory measures and build the capacity of authorities, domestic banks, and nonbank financial institutions in the following:

- Bhutan-worked with the Department of Financial Intelligence to finalize and publish an operating manual with a strategic plan, a guide on customer due diligence, and a technology road map for the continuous improvement of the Department of Financial Intelligence.

- Mongolia-partnered with the Financial Information Unit and the Financial Regulatory Commission in hosting a comprehensive 
training program attended by 19 financial institutions, which shared their compliance programs and approaches; establishing an AML/CFT division within the Financial Regulatory

Commission; drafting and finalizing two operating manuals; and conducting workshops on these manuals.

- Papua New Guinea-assisted the Financial Analysis and Supervision Unit in developing implementation arrangements for conducting risk-based customer due diligence, and reviewing the enabling environment for meeting AML/CFT requirements.

- Philippines-collaborated with the government in harmonizing the regulations of the three AML/CFT supervising authorities, developing a training course for the Anti-Money Laundering Council, establishing an AML/CFT division within the Securities and Exchange Commission, developing two guidelines and two operating manuals, and launching the Association of Certified Anti-Money Laundering Specialists (ACAMS) Philippine Chapter.

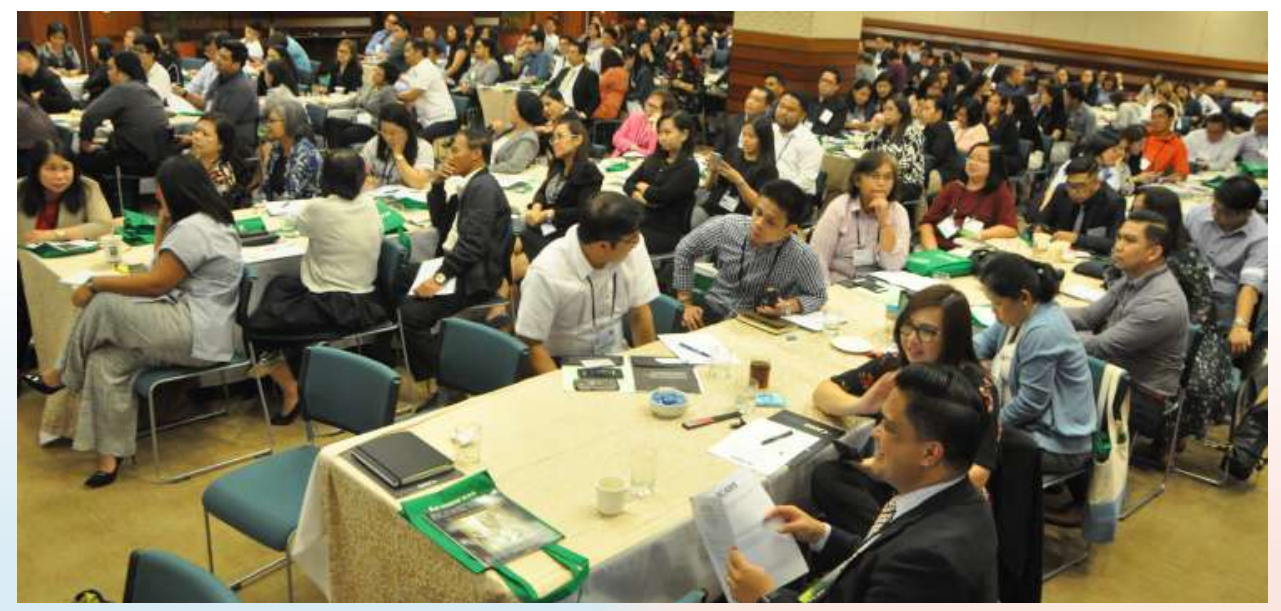

TA support for DMCs. ADB hosted the launch of the Association of Certified Anti-Money Laundering Specialists (ACAMS) Philippine Chapter, and its inaugural symposium on "Enhanced AML and Financial Crime Tools and Techniques" in June 2018 in Manila (photo by ACAMS Philippine Chapter Board).

Participants. The 15 capacity-building events in Mongolia, Papua New Guinea, and the Philippines were attended by 664 participants. 


\section{TA 9433: Enhancing Tax Transparency of ADB Developing Member Countries}

Milestones. Working with the Sustainable Development and Climate Change Department (SDCC) and the regional departments, OAl extended in-country technical assistance to seven DMCs to help them establish and enhance legal and institutional systems that would increase tax transparency and combat tax evasion. The Federated States of Micronesia, the Marshall Islands, and Samoa developed action plans for EOIR. Papua New Guinea and Thailand are developing their EOIR action plans, while Maldives and Thailand are preparing automatic exchange of information (AEOI) action plans.

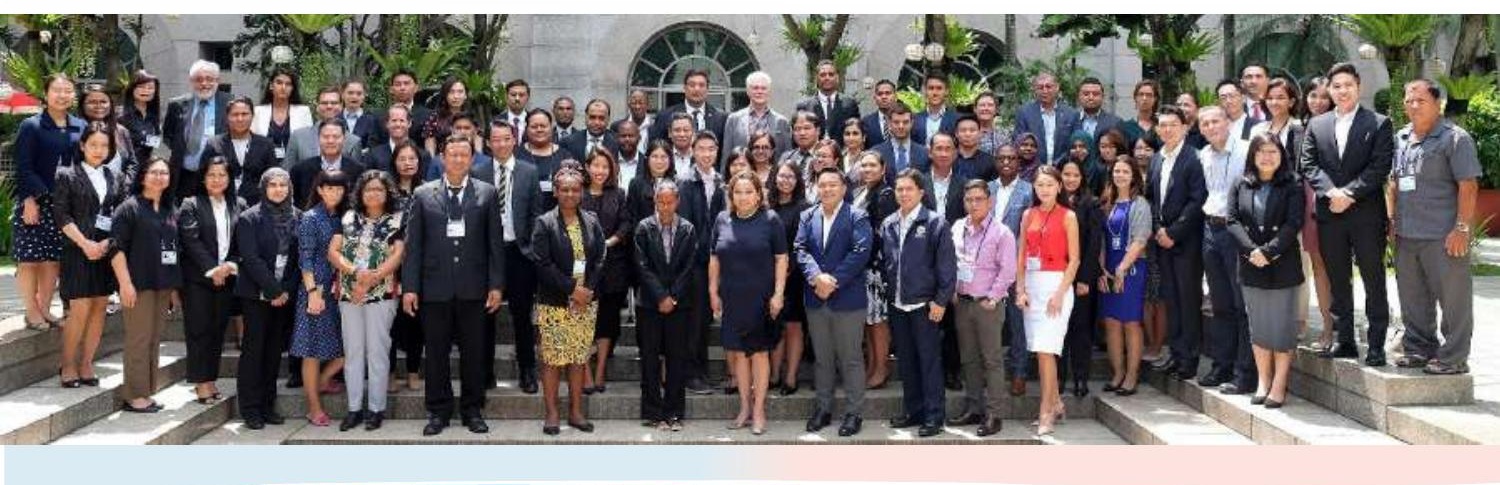

DMCs trained on beneficial ownership and exchange of information standards. Seventy senior officials and tax assessors from 27 jurisdictions, including 19 DMCs, participated in the training co-hosted by ADB and Global Forum in October 2018 in Manila.

Staff from the Philippine Senate involved in tax legislation were briefed on the fundamentals of AEOI to increase legislative awareness and facilitate their discussions with the Philippine Department of Finance.

OAI conducted eight regional knowledge-sharing events with other international organizations (OECD and Global Forum), regional organizations (Pacific Islands Tax Administrators Association), and tax administrations (Australian Taxation Office).

Participants. These in-country and regional events were attended by 766 participants from 35 DMCs. 


\section{ABOUT US}

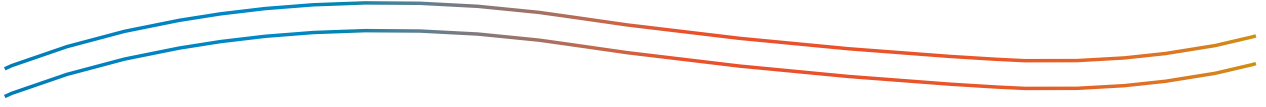

The Office of Anticorruption and Integrity (OAI) aligns its operations closely with ADB's Strategy 2030. OAI leads ADB's integrity and respect at work initiatives through the conduct of investigations, project procurement-related reviews, integrity due diligence, advisory, knowledge sharing, and capacity building with the bank's stakeholders.

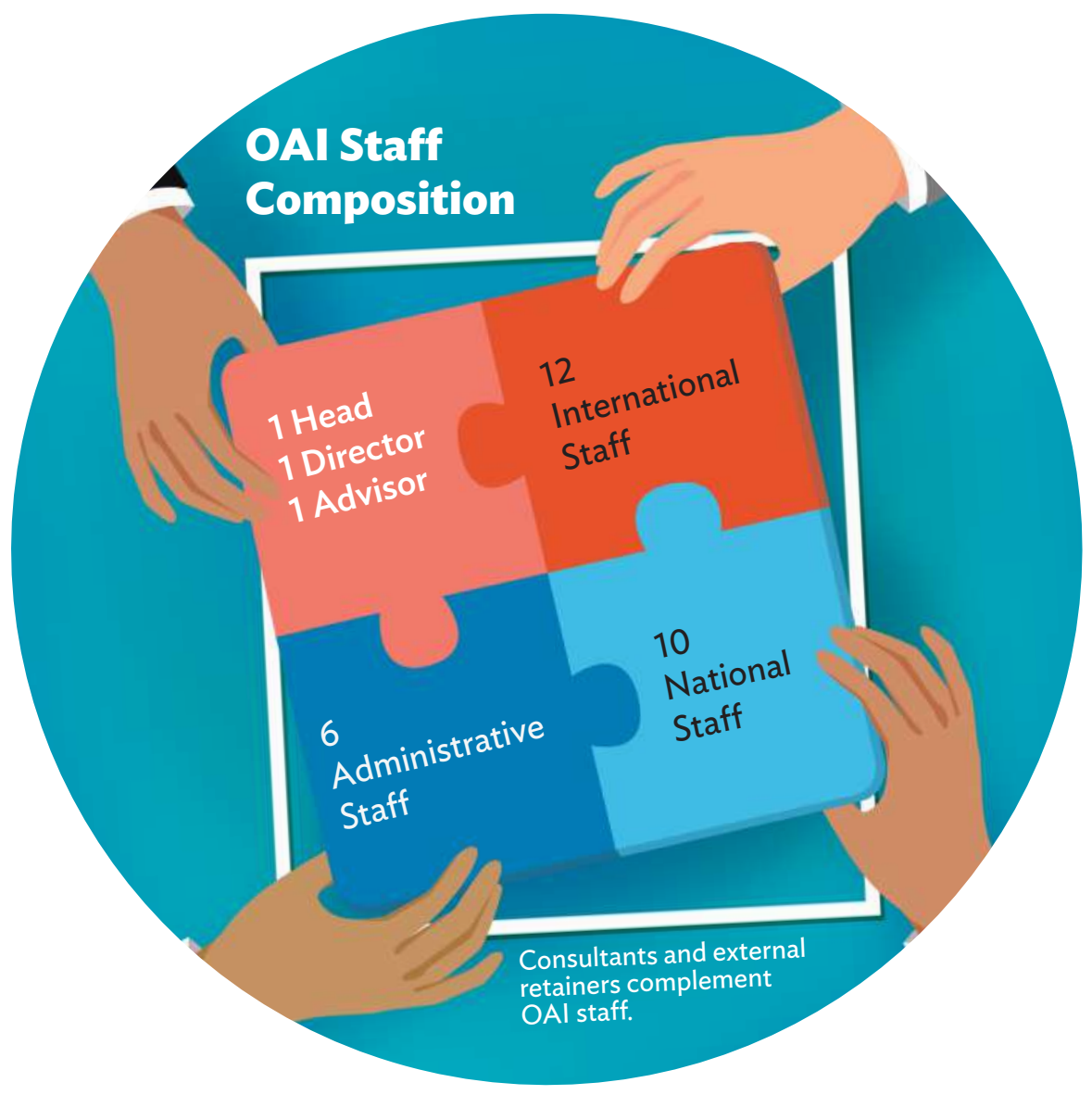


In 2018, OAl hosted two interns who conducted research related to respect at work and tax integrity. $\mathrm{OAI}$ also uses the services of consultants, contractors, and external investigation and audit firms, as needed.

To enhance collaboration among the members of its growing team, $\mathrm{OAI}$ relocated to an integrated and more secure office space. $\mathrm{OAl}$ is also at the forefront of the adoption of Office 365 at ADB, and is updating and enhancing its case management system to strategically align with ImaginelT, ADB's information technology modernization plan.

In delivering its mandate, OAI works closely with nearly all of ADB's other offices and departments, including the Office of the General Counsel, BPMSD, PSOD, the Office of Administrative Services, SDCC, and PPFD.

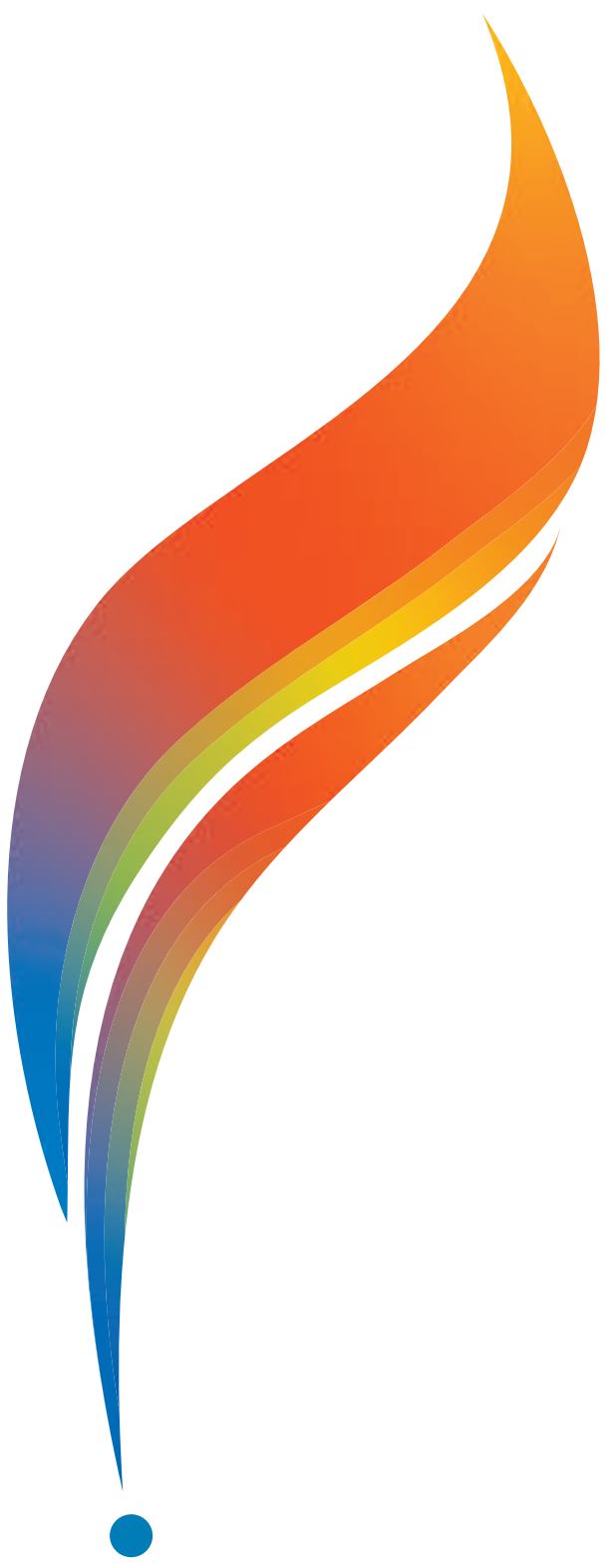




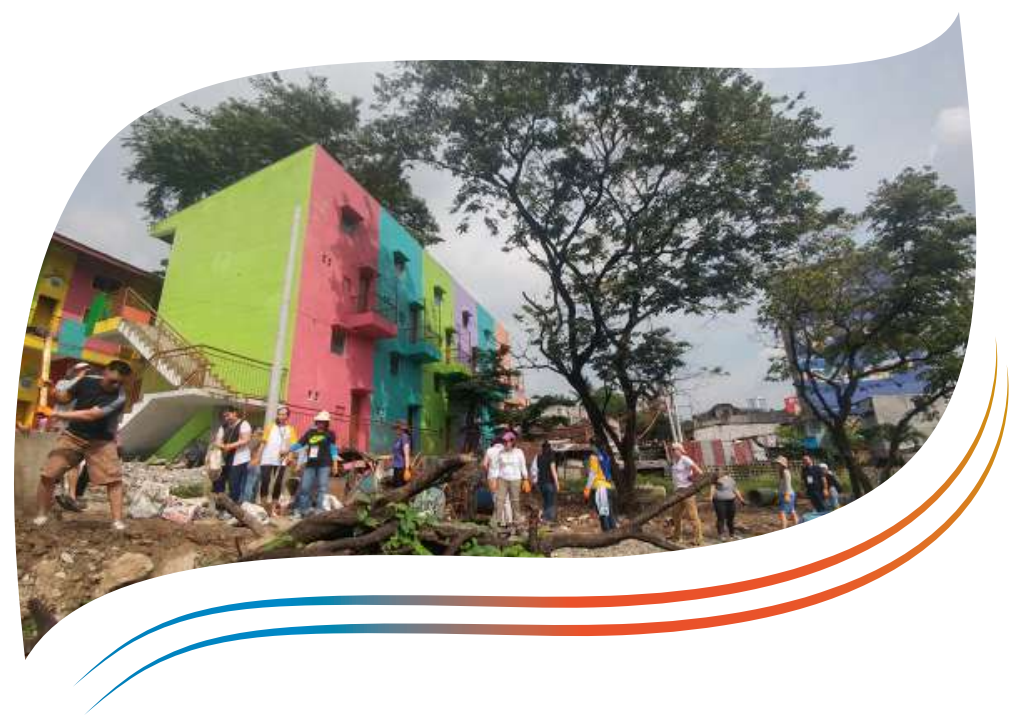

In September 2018, OAl staff and consultants volunteered at a Gawad Kalinga ("give care") village in Quezon City, Philippines. They helped lay the foundations for houses built for persons with disabilities and engaged with 40 children in the community through recreational activities. Gawad Kalinga is a poverty alleviation and community-building movement based in the Philippines.

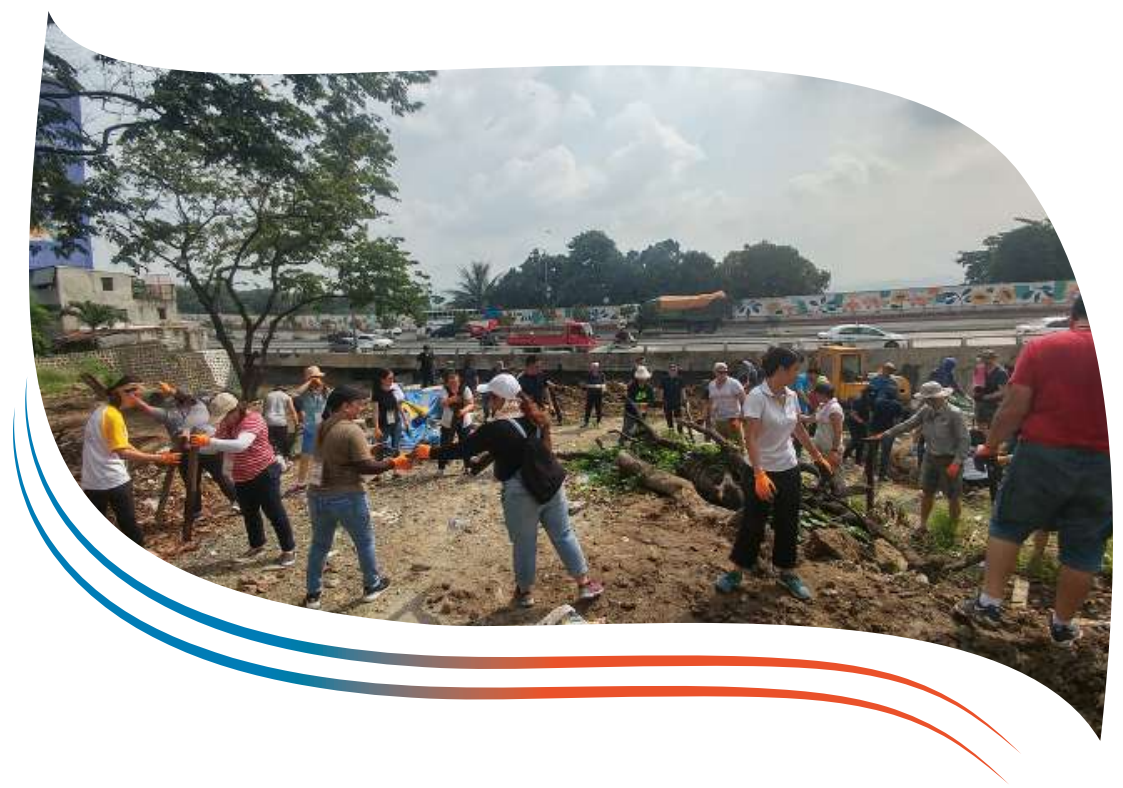




\section{APPENDIX A:}

\section{SAMPLE AIID INVESTIGATIONS}

In 2018, 20 investigations of external parties led to sanctions (Table A1.1).

Representative summaries are presented below.

Table A1.1: AIID Investigations of External Parties, 2018

\section{AllD's Investigative Findings \\ Resolution}

Fraud

An ADB consultant engaged in fraudulent practices by submitting falsified documentation for expenses ostensibly incurred for an ADB-financed TA. In evaluating the applicable debarment period, OAl considered the fact that the consultant had cooperated during the investigation and had offered to return the amount defrauded, besides the extent of harm caused to ADB.

During bid submission for an ADB-funded project, the executing agency established that the bid security extensions submitted by a firm for two contracts were fabricated.

OAl's investigation established that the firm's representative had provided falsified documents to comply with the requirements for the award of the contracts. The firm and its representative failed to cooperate with OAl's investigation.

The lead firm of a joint venture misrepresented a partner's engagement. During the investigation, the lead firm made false statements, failed to provide OAI with required documents, and did not respond to OAl's findings.
The consultant accepted OAl's proposed sanction period of 1 year with reinstatement, subject to the fulfillment of certain conditions.

The $I O C$ debarred the firm and its representative for 5 years. Their names were published in ADB's public sanctions list.

The IOC imposed a 6-year sanction on the lead firm and its director for fraudulent and obstructive practices. Their names were published in ADB's public sanctions list and submitted for cross-debarment. 


\section{AllD's Investigative Findings}

A large hydropower engineering company engaged in fraudulent practices and admitted to submitting fraudulent work experience documents.

An implementing agency determined that a firm had misrepresented its financial position in its bid submission. OAl's investigation confirmed that the firm had attempted to commit fraud to comply with the bid requirements.

The firm cooperated in OAl's investigation and conducted its own internal investigation, which led to the termination of the employee responsible for the misrepresentation.

A firm carried out an advance-fee fraud scam, using the names of $A D B$ senior management and the address of an ADB resident mission.

A consortium's lead firm submitted falsified end-user certificates, work contracts, and financial statements in its bid submission for an ADB contract. The firm also failed to provide supporting documents and adequate responses to OAI during its inquiries.

The firm's authorized representative was identified by the executing agency as having been responsible for submitting fraudulent documents in the firm's bid proposal. The representative admitted to preparing and submitting the fraudulent work experience documents, without the firm's knowledge.

\section{Resolution}

The company accepted OAl's proposed sanction period of 3 years. The sanction extended to the company's four subsidiaries and 29 branches. Reinstatement is subject to the fulfillment of certain conditions.

The firm accepted OAl's proposed sanction period of 2 years.

The IOC imposed a 3-year sanction on the firm and its representative. Their names were published on ADB's public sanctions list and submitted for cross-debarment.

The IOC imposed a 4-year sanction on the firm, its director, and its general manager. Their names were published in ADB's public sanctions list and submitted for cross-debarment.

The IOC imposed a 3.5-year sanction on the representative. His name was published in ADB's public sanctions list. 


\section{AllD's Investigative Findings}

An executing agency's due diligence during bid evaluation determined that a firm had submitted fraudulent documents in its bid for an

ADB-financed contract. According to OAl, the firm had submitted the fraudulent documents to make its bid responsive to the bid requirements. The firm cooperated fully in OAl's investigation.

A firm amended its business license in its bid submission to meet the required years of general experience.

A firm submitted fake documents in its bid for a contract for an ADB-financed project.

$A$ joint venture's lead firm and authorized representative submitted fraudulent work completion certificates in support of the joint venture's bid for an ADB-financed contract.

A consultant misrepresented his academic degree in an expression of interest submitted for an ADB consultancy position, to be more responsive to the requirements of the terms of reference. He cooperated in OAl's investigation.

A firm submitted fraudulent documents to make its bid responsive to the requirements.

\section{Resolution}

The firm accepted OAl's proposed sanction period of 3 years.

The IOC imposed a 5-year sanction on the firm and its representative.

The IOC imposed a 3-year sanction on the firm and its two key shareholders and/or directors.

The IOC imposed a 3-year sanction on the lead firm and the joint venture's authorized representative.

The IOC imposed a 2-year sanction on the consultant.

The firm accepted OAl's proposed sanction period of 2 years. 


\section{AllD's Investigative Findings}

Resolution

\section{Fraud and Obstructive Practices}

OAl identified inconsistencies in the work experience stated in a firm's CMS profile. OAI confirmed that the firm had misrepresented its work experience in CMS and found that the firm had obstructed OAl's inquiries into the initial allegation by refusing to provide its corporate information.

\section{Collusion}

A bidder submitted documents that were almost identical to another bidder's documents. OAI established that these bidders were related through a previous business relationship and had colluded.
The IOC imposed a 4-year sanction on the firm and three related individuals.

\section{Sanctions Violation}

A sanctioned firm attempted to bid for and win an ADB-financed contract.
The IOC imposed a 4-year sanction on the bidders and their representatives.
The firm agreed to the proposed additional sanction, which was later published in ADB's public sanctions list.

$\mathrm{ADB}=$ Asian Development Bank; AIID = Investigations Division, Office of Anticorruption and Integrity; CMS = Consultant Management System, IOC = Integrity Oversight Committee; $\mathrm{OAI}=$ Office of Anticorruption and Integrity; TA = technical assistance.

Note: The personal pronoun "he"/"his"/“him" is used here for the sake of convenience and is not gender-specific.

Source: Asian Development Bank (Office of Anticorruption and Integrity). 
In 2018, OAl's Investigations Division concluded three investigations involving ADB staff and submitted the investigation reports to the Budget, Personnel, and Management Systems Department (BPMSD). In the two cases presented below (Table A1.2), BPMSD issued a disciplinary action. The third case was under assessment at the end of 2018.

\section{Table A1.2: AIID Investigations Involving ADB Staff, 2018}

\begin{tabular}{l|l}
\hline AllD's Investigative Findings & Resolution \\
\hline Misconduct & \\
\hline $\begin{array}{l}\text { An ADB staff member did not make } \\
\text { the required declarations regarding } \\
\text { his personal financial interests. }\end{array}$ & BPMSD issued a written reprimand. \\
$\begin{array}{l}\text { The staff's omissions did not amount } \\
\text { to fraudulent practice because he did } \\
\text { not derive undue financial benefit. }\end{array}$ & \\
\hline $\begin{array}{l}\text { An ADB staff member misrepresented } \\
\text { the details of a transaction in a } \\
\text { document. He was aware that } \\
\text { ADB would submit the document } \\
\text { to government authorities. }\end{array}$ & BPMSD demoted the \\
\hline $\begin{array}{l}\text { His actions contravened the } \\
\text { highest ethical standards expected } \\
\text { of an ADB staff member and } \\
\text { constituted misconduct. }\end{array}$ & \\
\hline
\end{tabular}

$A D B=$ Asian Development Bank; AIID = Investigations Division, Office of Anticorruption and Integrity; BPMSD = Budget, Personnel, and Management Systems Department.

Note: The personal pronoun "he"/“his"/“him" is used here for the sake of convenience and is not gender-specific.

Source: Asian Development Bank (Office of Anticorruption and Integrity). 


\section{APPENDIX B: \\ 2018 SAMPLE AIOD-RWU INVESTIGATIONS}

In 2018, the Respectful Workplace Unit (AIOD-RWU) completed nine investigation reports on cases of bullying, harassment, and other forms of misconduct (Table A2.1). Of the nine reports, seven were submitted to the Budget, Personnel, and Management Systms Department. AIOD-RWU also resolved four matters with remedial action such as training and supervisory intervention.

Table A2.1: AIOD-RWU Investigations of Cases of Bullying, Harassment, and Other Forms of Misconduct, 2018

\section{AIOD-RWU's Investigative Findings $\quad$ Resolution}

\section{Bullying and Harassment and Other Misconduct}

An ADB staff member bullied,

BPMSD issued a written reprimand.

harassed, and abused his

authority over another staff.

An ADB staff member engaged in misconduct at an $\mathrm{ADB}$ event.

An ADB staff member attempted to

BPMSD issued a written censure. unduly influence a recruitment process.

An ADB staff member engaged in misconduct by behaving in a manner unbecoming of an international civil servant while interacting with a government official on duty.

An ADB staff member engaged in misconduct by behaving inappropriately, thus creating an intimidating and hostile work environment.
OAl completed its investigation report. The staff resigned, so ADB did not pursue disciplinary action. 


\section{AIOD-RWU's Investigative Findings}

\section{Resolution}

An ADB staff member bullied and harassed other staff and ignored official requests.

The matter was resolved, and appropriate remedial action was taken.

An ADB staff member engaged in misconduct by making inappropriate comments, shouting, and being discourteous.

An ADB staff member engaged in misconduct by intimidating and offending colleagues.

\section{Sexual Harassment}

An employee of an ADB service provider sexually harassed a staff of another ADB service provider.

The ADB service provider's employee who was alleged to have committed the misconduct was permanently reassigned outside $A D B$.

ADB = Asian Development Bank; BPMSD = Budget, Personnel, and Management Systems, Department, IOC = Integrity Oversight Committee;

$\mathrm{OAI}=$ Office of Anticorruption and Integrity; TA = technical assistance.

Note: The personal pronoun "he"/“his"/"him" is used here for the sake of convenience and is not gender-specific.

Source: Asian Development Bank (Office of Anticorruption and Integrity). 


\section{OFFICE OF ANTICORRUPTION AND INTEGRITY}

2018 ANNUAL REPORT

This publication reports on the 2018 initiatives of the Asian Development Bank's Office of Anticorruption and Integrity to foster integrity and to fight corruption in Asia and the Pacific, in collaboration with regional and international partners. These initiatives included conducting investigations, preventing project and integrity-related risks, tax integrity and anti-money laundering, developing measures to combat the financing of terrorism, integrity and respect in the ADB workplace, and the Anti-Corruption Initiative for Asia and the Pacific.

\section{About the Asian Development Bank}

$A D B$ is committed to achieving a prosperous, inclusive, resilient, and sustainable Asia and the Pacific, while sustaining its efforts to eradicate extreme poverty. Established in 1966, it is owned by 68 members -49 from the region. Its main instruments for helping its developing member countries are policy dialogue, loans, equity investments, guarantees, grants, and technical assistance.

\section{$\mathrm{ADB}$}

